\title{
Evidence for hydrothermal venting in Fe isotope compositions of the deep Pacific Ocean through time
}

\author{
N.-C. Chu ${ }^{\mathrm{a},{ }^{*},}$, C.M. Johnson ${ }^{\mathrm{b}}$, B.L. Beard ${ }^{\mathrm{b}}$, C.R. German ${ }^{\mathrm{a}}$, R.W. Nesbitt ${ }^{\mathrm{a}}$, M. Frank ${ }^{\mathrm{c}}$, Marcel \\ Bohn $^{d}$, P.W. Kubik ${ }^{\text {e }}$ A. Usuif, I. Graham ${ }^{g}$
}

\author{
${ }^{a}$ National Oceanography Centre, Southampton, SO14 3ZH, UK \\ ${ }^{\mathrm{b}}$ Department of Geology and Geophysics, University of Wisconsin-Madison, 1215 West Dayton Street, Madison, \\ WI 53706, USA \\ ${ }^{C}$ Institute for Isotope Geology and Mineral Resources, Department of Earth Sciences, ETH-Zentrum, NO F51.3, \\ Sonneggstrasse 5, CH-8092 Zürich, Switzerland \\ ${ }^{\mathrm{d}}$ Microsonde Ouest, IFREMER and CNRS, Centre de Brest, 29280 Plouzané, France \\ ${ }^{\text {e}}$ Paul Scherrer Institute, c/o Institute for Particle Physics, ETH Hönggerberg, CH-8093 Zürich, Switzerland \\ ${ }^{f}$ Department of Earth History and Environmental Science, Kochi University, Japan \\ ${ }^{g}$ Institute of Geological and Nuclear Sciences, Wellington, New Zealand
}

*: Corresponding author : N.-C. Chu, email address : Nanchin.Chu@ifremer.fr

\begin{abstract}
:
Temporal variations in Fe isotope compositions at three locations in the Pacific Ocean over the last 10 $\mathrm{Ma}$ are inferred from high-resolution analyses of three hydrogenetic ferromanganese crusts. Iron pathways to the central deep Pacific Ocean appear to have remained constant over the past $10 \mathrm{Ma}$, reflected by a remarkably constant $\mathrm{Fe}$ isotope composition, despite large changes in the Fe delivery rates to the surface ocean via dust. These results suggest that the Fe cycle in the deep ocean is decoupled from that in surface waters. By contrast, one ferromanganese crust from the Izu-Bonin (IB) back-arc/marginal basin of the W. Pacific exhibits large $\delta^{56} \mathrm{Fe}$ variations. In that crust, decreases in $\delta^{56} \mathrm{Fe}$ values correlate with increases in $\mathrm{Mn}, \mathrm{Mg}, \mathrm{Ni}, \mathrm{Cu}, \mathrm{Zn}, \mathrm{Mo}$, and $\mathrm{V}$ contents, and consistent with periods of intense hydrothermal input and increased growth rates. A second crust located within 100 $\mathrm{km}$ of the first IB sample does not record any of these periods of enhanced hydrothermal input. This probably reflects the isolated pathways by which hydrothermally sourced Fe may have migrated in the back arc, highlighting the high degree of provinciality that Fe isotopes may have in the modern (oxic) oceans. Our results demonstrate that despite efficient removal at the source, hydrothermal Fe injected into the deep ocean could account for a significant fraction of the dissolved Fe pool in the deep ocean, and that hydrothermally sourced Fe fluxes to the open ocean may have lower $\delta^{56} \mathrm{Fe}$ values than those measured so far in situ at hydrothermal vents. Correlation between $\delta^{56} \mathrm{Fe}$ values and elements enriched in hydrothermal fluids may provide a means for distinguishing hydrothermal Fe from other low- $\delta^{56} \mathrm{Fe}$ sources to the oceans such as dissolved riverine $\mathrm{Fe}$ or porewaters in continental shelf sediments.
\end{abstract}

Keywords: Fe isotopes; ferromanganese crusts; hydrothermal; Izu-Bonin; Pacific Ocean

\section{Introduction}

Over the past 15 years there has been increasing interest in the cycling of dissolved Fe in the world's oceans and, in particular, the role that Fe availability plays 
in controlling phytoplankton growth across large areas of the world's surface ocean.

This link is significant because phytoplankton productivity is directly tied to the draw down of atmospheric $\mathrm{CO}_{2}$, and therefore can influence global climate cycles $[1,2]$. Much attention has been paid to deciphering Fe sources in the ocean and, in particular, the relative contribution of atmospheric input vs continental weathering [3]. Fewer studies, by contrast, have focused on the cycling of dissolved Fe in the deep ocean [4-6], even though upwelling from deep waters may represent an important source of dissolved $\mathrm{Fe}$ in surface waters $[7,8]$. Because the residence time of Fe in seawater is very short (70-140 years) [9], it is difficult to identify Fe cycling pathways based on Fe concen trations alone. However, iron isotopes fractionate via variou s processes and therefore hold great promise for tracing the marine biogeochemical cycle of this important micronu trient [10].

One approach to using Fe iso topes to trace Fe cycling in marine environments is the investigation of the temporal variability of Fe isotope composition in the oceans, as recorded in hydrogenetic ferromanganese crusts, on a time scale of millions of years. To date, only one marine Fe isotope time-series is available from the NW Atlantic Ocean [11] (Fig. 1), which shows close correlations between Fe and $\mathrm{Pb}$ isotope composition s, particularly over the past 1 Ma. However, Levasseur et al. [12] have recently re-analysed the 3 top-most layers from the same crust and failed to find any $\delta^{56} \mathrm{Fe}$ values $>-0.4 \%$, contrary to the prior analysis by Zhu et al. [11], although the $\mathrm{Pb}$ isotope compositions in both studies agreed. The origin of this discrepancy remains unknown, and further studies of temporal Fe isotope variations in the North Atlantic Ocean are needed.

A single Fe isotope record is insufficient to constrain the temporal variability in Fe isotope variations in the oceans because the short residence time of dissolved Fe 
suggests that significant inter- and even intra-basin differences in Fe isotope compositions most probably exist $[9,13]$. Significant Fe isotope heterogeneity has been confirmed recently in a study that identified a broad Fe isotope variability in surface layers of ferromanganese crusts from the whole world ocean [12]. To assess both temporal and geographic variability in the Fe isotope record, we selected three ferromanganese crusts from two areas of the Pacific Ocean (Central Pacific and Izu-Bonin back arc basin) and report temporal records for the isotopic composition of dissolved Fe extending back over the past 5-10 Ma.

\section{Material and analytical methods}

We have studied three ferromanganese crusts: one from the deep Central Pacific Ocean (28DSR9: $4^{\circ} 10^{\prime} \mathrm{S}, 174^{\circ} 54^{\prime} \mathrm{W}, 3033 \mathrm{~m}$ water depth, 0-10 Ma) and two other crusts collected from the Izu-Bonin Arc region of the marginal West Pacific (D105-5AB: $31^{\circ} 22^{\prime} \mathrm{N}, 138^{\circ} 41^{\prime} \mathrm{E}, 2120 \mathrm{~m}$ depth, 0-5 Ma; D97- 1: $30^{\circ} 53^{\prime} \mathrm{N}, 138^{\circ} 22^{\prime} \mathrm{E}$, $2540 \mathrm{~m}$ depth, 0-5 Ma) (Fig. 1) [14]. All three crusts had grown on basaltic substrates. No secondary alteration features such as carbonate fluorapatite or other evidence of phosphatisation events [15] were observed in the samples.

The growth rates of each sample were determined by the ${ }^{10} \mathrm{Be} /{ }^{9} \mathrm{Be}$ method. For sample 28DSR9 and D97-1, ${ }^{10}$ Be concen trations were measured at the AMS facility of the Paul Scherrer Institute and the ETH, Zürich, Switzerland following standard chemical preparation methods [16]. The ${ }^{10} \mathrm{Be}$ concentrations were normalised to internal standard S555 with a nominal ${ }^{10} \mathrm{Be} /{ }^{9} \mathrm{Be}$ of $9.55 \times 10^{-11} . \quad{ }^{9} \mathrm{Be}$ concentrations were obtained from the same aliquots by ICP-MS (PlasmaQuad 2+, VG Elemental) at the National Oceanography Centre, Southampton (NOCS). For sample D105-5AB, ${ }^{10} \mathrm{Be}$ measurements were carried out at Lower Hutt, New Zealand and normalised to the NIST standard SRM4325, with a nominal ${ }^{10} \mathrm{Be} /{ }^{9} \mathrm{Be}$ of 
$3.06 \times 10^{-11}$.

Sample powders were obtained at 0.5 to $1 \mathrm{~mm}$ resolution from a

resin-embedded sample section by a computer-controlled milling instrument at ETH Zürich. All samples analysed here were digested in warm $6 \mathrm{M} \mathrm{HCl}$ and separated from any und issolved residues by centrifugation, although where present, residues comprised a very minor component of the sample based on visual inspection and $\mathrm{Si}$ and $\mathrm{Al}$ contents (see below). Treatment in warm $6 \mathrm{M} \mathrm{HCl}$ will not fractionate $\mathrm{Fe}$ isotope compositions of oxide minerals because they dissolve such minerals congruently [e.g., 10]. For Fe isotope measurements, all samples were purified by anion-exchan ge chromatography following previously established methods [17]. Analyses were carried out on a MC-ICP-MS (IsoProbe, GV Instruments) at the University of Wisconsin, Madison. Instrumental mass bias was corrected using a standard-sample-standard bracketing approach. Iron isotope v ariations are reported as $\delta^{56} \mathrm{Fe}$ and $\delta^{57} \mathrm{Fe}$ values: $\delta^{56} \mathrm{Fe}=\left({ }^{56} \mathrm{Fe} /{ }^{54} \mathrm{Fe}\right.$ sample $\left./{ }^{56} \mathrm{Fe} /{ }^{54} \mathrm{Fe}_{\text {Igneous Rocks }}-1\right) \times 10^{3}$, where the reference ratio ${ }^{56} \mathrm{Fe} /{ }^{54} \mathrm{Fe}_{\text {Igneous Rocks }}$ is defined by the average of 46 igneous rocks $\left(\delta^{56} \mathrm{Fe}=0.00 \pm 0.05 \% ;[17]\right) . \quad$ The measured $\mathrm{Fe}$ isotope compositions of three standard s measured during the course of this study were: $\mathrm{J}-\mathrm{M} \mathrm{Fe}, \delta^{56} \mathrm{Fe}=0.27 \pm 0.07 \%$, $\delta^{57} \mathrm{Fe}=0.41 \pm 0.10 \%$ ( $\left.1 \mathrm{SD}, \mathrm{n}=49\right) ; \mathrm{HPS} \mathrm{Fe}, \delta^{56} \mathrm{Fe}=0.49 \pm 0.06 \%$ o, $\delta^{57} \mathrm{Fe}=0.74 \pm 0.06 \%$ 。 (1SD, $\mathrm{n}=15)$; IRMM-014, $\delta^{56} \mathrm{Fe}=-0.10 \pm 0.07 \%$, $\delta^{57} \mathrm{Fe}=-0.08 \pm 0.13 \% \circ(1 \mathrm{SD}, \mathrm{n}=49)$. These uncertainties are similar to those obtained on different aliquots passed through ion exch ange chemistry and are therefore considered to also reflect the external reproducibility of samples.

Ferromanganese crusts contain signific ant quantities of transition metals that, if present in the solutions analysed for Fe isotope compositions, can impart significant differences in instrumental mass bias relative to bracketing standards. The accuracy 
of the Fe isotope analyses is demonstrated through tests using artificial Fe-Mn-Co mixtures and Fe of known isotopic composition, and these tests show that our analytical meth ods correctly determine the Fe isotope compositions of the crusts (Suppl. Table 1).

Lead isotope and elemental compositions were measured on selected samples from each ferromanganese crust. Lead was extracted using ion-exchange chromatography [18], followed by isotopic analysis by MC-ICP-MS (IsoProbe, GV Instruments) at NOC, where instrumental mass bias was corrected using Tl that was added to the solutions [19]. Elemental abundances were determined by ICP-AES (Optima 2000DV, Elmer-Perkin). The elemental concentrations were determined following $6 \mathrm{M} \mathrm{HCl}$ leaching of around $0.02 \mathrm{~g}$ dry milled powders, which is an order of magnitude larger than those for Fe chemistry. In addition, elemental compositions for D97-1 were also measured at a higher spatial resolution $(\sim 100 \mu \mathrm{m})$ by Electron Probe Micro-analysis (EPMA) (SX50, Cameca) at Ifremer, France. In addition to providing a higher spatial resolution for chemical compositions, comparison of compositions determined by ICP-AES and EMPA provide an assessment of any bias produced by partial dissolution. Polished sections were made on the counterpart of the sample that was micro drilled, where available. Analyses were obtained using oxide standards at an accelerating voltage of $15 \mathrm{kV}$ with a sample current of $12 \mathrm{nA}$.

\section{Results}

We discuss first the age model determined by ${ }^{10} \mathrm{Be} /{ }^{9} \mathrm{Be}$ ratios, followed by a presentation of $\mathrm{Fe}$ isotope and elemental variations and, finally, $\mathrm{Pb}$ isotope compositions.

\subsection{Age models}

${ }^{10} \mathrm{Be}$ and ${ }^{9} \mathrm{Be}$ concentrations, ${ }^{10} \mathrm{Be} /{ }^{9} \mathrm{Be}$ ratios, and calculated growth rates of all 
three crusts are shown in Figure 2 (data given in Suppl. Table 2). The oldest ages of all three crusts are less than $10 \mathrm{Ma}$, and therefore the ${ }^{10} \mathrm{Be}$ ages provide reliable crust chronologies without the need for additional chronology corrections (such as by using the Co constant flux method). $\quad{ }^{10} \mathrm{Be} /{ }^{9} \mathrm{Be}$ ratios for the Central Pacific sample, 28DSR9, lie along a linear trend with sampling depth, suggesting a near constant growth rate of $3.7 \mathrm{~mm} / \mathrm{Ma}$. There is greater scatter in ${ }^{10} \mathrm{Be} /{ }^{9} \mathrm{Be}$ ratios with depth for the two Izu-Bonin samples, possibly indicating three periods of growth at different rates in $\mathrm{D} 105-5 \mathrm{AB}(3.7,20.8$, and $5.7 \mathrm{~mm} / \mathrm{Ma})$ and four periods in $\mathrm{D} 97-1(3.5,12.4$, 4.3, and $12.4 \mathrm{~mm} / \mathrm{Ma}$ ) (Fig. 2, Suppl. Table 2).

\section{$3.2 \mathrm{Fe}$ isotope compositions}

$\delta^{56} \mathrm{Fe}$ values of 28DSR9 (Central Pacific crust) have remained ess entially constant $\left(\delta^{56} \mathrm{Fe}=-0.41 \pm 0.05,1 \mathrm{SD}\right)$ throughout the past 10Ma (Fig.3, Suppl. Table 3) Crust D105-5AB from the Izu-Bonin back arc also has nearly constant $\delta^{56} \mathrm{Fe}$ values $\left(\delta^{56} \mathrm{Fe}=-0.55 \pm 0.06,1 \mathrm{SD}\right)$ throughout the past $5 \mathrm{Ma}$ (Fig. 3, Suppl. Table 4), although the average $\delta^{56} \mathrm{Fe}$ value is lower than that of the Central Pacific crust. In contrast, the isotopic variations for crust D97-1 (Fig. 3, solid triangles, Suppl. Table 5) are distinct from those of the other two crusts. $\delta^{56} \mathrm{Fe}$ values that are more negative than those found in the Central Pacific sample are common throu ghout crust D97-1 over the past $4 \mathrm{Ma}$, where significant deviations to even more negative values occur at 3.7-2.2 $\mathrm{Ma}\left(\delta^{56} \mathrm{Fe}=-0.69 \pm 0.05\right), 2.0-1.2 \mathrm{Ma}\left(\delta^{56} \mathrm{Fe}=-0.77 \pm 0.04\right)$, and from $0.1 \mathrm{Ma}$ to present $\left(\delta^{56} \mathrm{Fe}\right.$ as low as -0.9$)$.

\subsection{Chemical compositions}

All analysed layers of the three crusts fall within the hydrogenetic category defined by a conventional ternary plot, using end members of $\mathrm{Fe}-\mathrm{Mn}-10 *(\mathrm{Ni}+\mathrm{Cu})[20$, 21] (Supplementary Fig. 1). All three crusts display light REE enriched profiles and 
a positive Ce anomaly (Supplementary Fig 2) [22], which also confirm their hydrogenetic origin. Detrital silicate minerals cannot be a major source for Fe because $\mathrm{Si}$ and $\mathrm{Al}$ contents determined by EPMA are less than 8 and 3 wt. \%, respectively. Moreover, $\mathrm{Si}$ and $\mathrm{Al}$ contents in the bulk powder dissolutions are less than 1 wt. \% (determined by ICP-AES), indicating effective isolation of hydrogenetic Fe during dissolution in warm $6 \mathrm{M} \mathrm{HCl}$. The largest temporal variations in elemental compositions occur in Izu-Bonin sample D97-1, which also has the largest range in Fe isotope compositions (Fig. 4). With the exception of the two topmost layers, two periods of continuously lowered $\delta^{56} \mathrm{Fe}$ and significant changes in major element concentrations in D97-1 occurred during periods of enhanced growth rates (growth rate at $12.36 \mathrm{~mm} / \mathrm{Ma}$ from 3.7 to $4.5 \mathrm{Ma}$ and from 1.8 to $2.4 \mathrm{Ma}$ ). In contrast, the Central Pacific sample (28DSR9) has relatively constant major element and $\mathrm{Fe}$ isotope compositions over time. Similarly, Izu-Bonin sample D105-5AB exhibits near-constant $\mathrm{Mn}, \mathrm{Fe}, \mathrm{Cu}, \mathrm{Ni}, \mathrm{Mg}$, and $\mathrm{Zn}$ contents over time.

Elements such as $\mathrm{Mn}, \mathrm{Mg}, \mathrm{Ni}, \mathrm{Cu}, \mathrm{Zn}, \mathrm{Mo}$, and $\mathrm{V}$ are correlated with $\delta^{56} \mathrm{Fe}$ values for crust D97-1 (Fig. 5), where decreasing $\delta^{56} \mathrm{Fe}$ values are accompanied by increases in the abundance of these elements. In several cases, the $\delta^{56} \mathrm{Fe}$-element variations for D97-1 are offset from the clusters of data from 28DSR9 and/or D105-5AB (Fig. 5). Additional Fe, Mn, and Ti EPMA profiles of D97-1 (Fig. 6, grey solid lines) provide a higher resolution $(\sim 100 \mu \mathrm{m})$ than those obtained with the bulk-powder ICP-AES data (open circles). There is a good correlation between EPMA and ICP-AES elemental profiles, which suggests that dilution effects induced by the undissolved detritus fractions prior to ICP-AES analyse were negligible for most elements, consistent with the low $\mathrm{Si}$ and $\mathrm{Al}$ contents noted above. Afew of the bulk-powder samples (e.g. 1.8 Ma, Fig. 6, open circles) have higher Fe 
concentrations than those expected based on the EPMA profile. The higher-resolution EPMA profiles confirm the positive correlation between $\mathrm{Ti}$ and $\delta^{56} \mathrm{Fe}$ values, despite the fact that the sample size used for the Fe isotope analyses was much larger (1-2 mg). The negative correlation between $\mathrm{Mn}$ and $\delta^{56} \mathrm{Fe}$ that is observed in the bulk-powder samples (Fig. 5) is also seen when using the EPMA Mn profiles (Fig. 6; note reversal in Mn scale in the figure). Two profiles of Fe/Mn and $\mathrm{Co} / \mathrm{Mn}$ also correlate with $\delta^{56} \mathrm{Fe}$ (Fig. 6b), which provides further evidence of this elemental co-variation in sample D97-1 even when dilution effects introduced during sample preparations, e.g. from the resin, are completely removed

\subsection{Pb isotopes}

Lead isotope compositions of the Central Pacific sample 28DSR9 have varied within a small range over the past $6 \mathrm{Ma}\left({ }^{206} \mathrm{~Pb} /{ }^{204} \mathrm{~Pb}\right.$ ratios lie between 18.71 and 18.73, Fig. 7). This is in agreement with data previously reported from North Central Pacific ferromanganese crusts [23-25], but distinctly different from the large $\mathrm{Pb}$ isotope variability found in the northernmost Pacific Ocean [26]. The two Izu-Bonin samples, D105-5AB and D97-1, also show small variations over the past 5 $\mathrm{Ma}\left({ }^{206} \mathrm{~Pb} /{ }^{204} \mathrm{~Pb}=18.54\right.$ to 18.59$)$. As observed by Levasseur et al. [12] for crust surfaces, there is not a strong correlation between $\mathrm{Pb}$ isotope compositions and $\delta^{56} \mathrm{Fe}$ values for the ferromangan ese crusts of this study (Fig. 7).

\section{Discussion}

As first highlighted by Johnson et al. [27] and Beard et al. [13], as well as in later studies [28], the short residence time for Fe in the modern ocean results in $\mathrm{Fe}$ isotope provinciality among the oceans basins, possibly on a local scale. Our results provide insights in to the temporal Fe isotope variations at two different Pacific locations, which is complementary to the global Fe isotope survey of surface layers from ferromanganese crusts presen ted by Levasseur et al. [12]. Interpretation of the 
origin of the Fe isotope variations measured in this study requ ires understanding of the possible pathways and sources for dissolved Fe that was sequestered, eventually, in to ferromanganese crusts. Possible Fe iso tope fractionation during crust formation is considered first below, followed by discussion of the various sources of Fe to the deep ocean and how they may be recorded in ferromanganese crusts.

\subsection{Is there Fe isotope fractionation during ferromanganese crust growth?}

The effects of possible isotopic fractionation upon precipitation are largely dependent upon the existence of intermed iate species, the residence time of an element, and the intrinsic fractionation factors. The potential role of an intermediate reservoir in determining the isotopic compositions of ferromanganese crusts relative to the overlying water column may be illustrated by a simple flow-through "box model", adapted from the equations and principles presented by DePaolo [29], where the "box" is an arbitrary volume of ambient seawater that might be envisioned to lie immediately adjacent to the ferromanganese crust (Fig. 8a). We assume that the incoming Fe flux from the overlying water column $\left(\mathrm{J}_{\mathbb{N}}\right)$ is equal to the flux out of the seawater reservoir $\left(\mathrm{J}_{\mathrm{OUT}}\right)$, and that the Fe concentration in this intermediate reservoir remains constant. We further assume that the initial $\delta^{56} \mathrm{Fe}$ value for the reservoir is equal to that of the incoming Fe flux, but that there may be an Fe iso tope fractionation during precipitation between the local seawater reservoir and the ferromanganese crust, which we define as $\Delta_{\text {CRUST-Sw }}=\delta^{56} \mathrm{Fe}_{\mathrm{CRUST}}-\delta^{56} \mathrm{Fe}_{\mathrm{SW}}$. The precipitation progress is described in terms of the integrated mass ratio of incoming flux relative to the mass of the ambient seawater reservoir, defined as $R=M_{I N} / M_{S w}$. Finally, we define the Fe distribution coefficient between ferroman ganese crust and the ambient seawater reservoir as $\mathrm{D}=\mathrm{C}_{\mathrm{CRUST}} / \mathrm{C}_{\mathrm{SW}}$. Re-arrangement of the equations in DePaolo (1981) (Eqs. 3 and 17 in the original paper) into the parameters defined above 
produces the following equation for the Fe contents in the local seawater reservoir:

$$
\mathrm{C}_{\mathrm{SW}}=\mathrm{C}_{\mathrm{SW}}{ }^{0} \bullet\left\{\mathrm{C}_{\mathrm{IN}} /\left(\mathrm{C}_{\mathrm{SW}}{ }^{0} \cdot \mathrm{D}\right) \cdot[1-\exp (-\mathrm{D} \cdot \mathrm{R})]+\exp (-\mathrm{D} \cdot \mathrm{R})\right\}
$$

where $\mathrm{C}_{\mathrm{SW}}{ }^{0}$ is the initial $\mathrm{Fe}$ concentration in the ambient seawater reservoir. In the calculations illustrated in Figure 8, we restrict $\mathrm{C}_{\mathrm{IN}}, \mathrm{C}_{\mathrm{Sw}}{ }^{0}$, and $\mathrm{D}$ to values that maintain $\mathrm{C}_{\mathrm{SW}}$ at a constant value, to be consistent with the restriction that $\mathrm{J}_{\mathbb{N}}=\mathrm{J}_{\text {OUT }}$. The accompanying change in $\delta^{56} \mathrm{Fe}$ values for the ambient seawater reservoir, as a function of $\mathrm{R}$, is given by the equation:

$$
\delta^{56} \mathrm{Fe}_{\mathrm{SW}}=\delta^{56} \mathrm{Fe}_{\mathrm{IN}}-\Delta_{\mathrm{CRUST}-\mathrm{SW}} \cdot[1-\exp (-\mathrm{D} \cdot \mathrm{R})] \text {, }
$$

and the instantaneous $\delta^{56} \mathrm{Fe}_{\text {CRUST }}$ value is given by:

$$
\delta^{56} \mathrm{Fe}_{\mathrm{CRUST}}=\Delta_{\text {CRUST-SW }}+\delta^{56} \mathrm{Fe}_{\mathrm{SW}} .
$$

Considering an element such as Fe, which has a short residence time (i.e., higher distribution coefficient $\mathrm{D}$ in this calculation), the $\delta^{56} \mathrm{Fe}$ value for the ferromanganese crust would rapidly shift toward the Fe isotope composition of the influx from the overlying water column, because Fe in the local seawater reservoir entirely accommodates any isotopic fractionation between seawater and crust (Fig. 8b). In contrast, if Fe had a long residence time in the ocean, a significant flux through the local seawater reservoir would be required before the ferromanganese crust reaches the Fe isotope composition of the influx (Fig. 8b). In this case, inferring the isotopic composition of the overlying water column from the Fe isotope composition of the crusts depends critically upon knowing the crust-seawater isotope fractionation factor. Such a case may be applicable to Mo and $\mathrm{Tl}$ iso tope variations in ferroman gan ese crusts, where significant isotopic fractionations have been measured between soluble and solid phases for these elements [30, 31], and whose moderately long $\left(10^{4}-10^{6} \mathrm{yr}\right)$ residence times make it essentially impossible to infer the isotopic compositions of the overlying water column (Fig. 8b). 
The $\Delta_{\text {CRUST-Sw }}$ fractionation factor is unknown, although we would expect it to be close to equilibrium given the very slow growth rates $(\sim 1-10 \mathrm{~mm} / \mathrm{Ma})$. The equilibrium fractionation between $\left[\mathrm{Fe}^{\mathrm{III}}\left(\mathrm{H}_{2} \mathrm{O}\right)_{6}\right]^{3+}$ and ferric oxide (hematite) at low temperatures $\left(<100{ }^{\circ} \mathrm{C}\right)$ is estimated to be near zero [32], suggesting that $\Delta_{\text {CRUST-SW }}$ should be zero if hexaquo Fe(III) was the primary soluble Fe species. It is certainly possible, however, that soluble Fe(III) may be bound to organic ligands in seawater $[33,34]$ prior to incorporation into ferromanganese crusts, and such fractionation factors are unknown but might be significant [35]. Despite the uncertainty in $\Delta_{\text {CRUST-SW }}$ fractionation, the very short residence time for Fe in the modern (oxic) oceans strongly suggests that the $\delta^{56} \mathrm{Fe}$ values in ferromanganese crusts directly reflect those of the overlying water column, based on the calculations illustrated in Figure 8b.

\subsection{Dust input to the deep Pacific Ocean Fe budget over past $10 \mathrm{Ma}$}

Lead isotope composition in ferromanganese crusts may be a sensitive indicator of aeolian dust and aerosol inputs to the oceans, although the link between atmospheric inputs and $\mathrm{Pb}$ isotope composition of $\mathrm{Fe}-\mathrm{Mn}$ crusts in the Pacific Ocean remains controversial [e.g.25, 26, 36, 37, 38]. The constant $\mathrm{Pb}$ isotope compositions over time for the three ferromanganese crusts of this study suggest that $\mathrm{Pb}$ sources have remained constant with time. The measured $\mathrm{Pb}$ isotope compositions of the Fe-Mn crusts are consistent with results obtained for leachates of Asian dust (Fig. 7), a conclusion also reached by Ling et al. [25] for ferromanganese crusts from other localities in the North Pacific Ocean. There is no evidence that any significant mantle-derived $\mathrm{Pb}$ was incorporated in our three crusts because mid-ocean ridge basalts [39] and Izu-Bonin arc rocks have significantly lower ${ }^{206} \mathrm{~Pb} /{ }^{204} \mathrm{~Pb}$ and 
${ }^{207} \mathrm{~Pb} /{ }^{204} \mathrm{~Pb}$ ratios (Fig. 7). We do observe, however, that the two IB crusts are significantly less radiogenic in ${ }^{206} \mathrm{~Pb} /{ }^{204} \mathrm{~Pb}$ ratios than the Central Pacific crust.

Atmospheric dust input is the dominant source for Fe delivery to the upper oceans far from continental margins $[3,40]$, such as the location of the Central Pacific sample 28DSR9. The $\delta^{56} \mathrm{Fe}$ values for aeolian Fe would lie near zero [13], and it seems probable that partial dissolution of aeolian particles in seaw ater would produce dissolved $\mathrm{Fe}$ that had low $\delta^{56} \mathrm{Fe}$ values [12]. If delivery of atmospheric dust was an important flux for Fe to the deep Central Pacific Ocean that was sequestered in crust 28DSR9, either through settling of dust particles $\left(\delta^{56} \mathrm{Fe}=0\right)$ or partial dissolution by organic ligands $\left(\delta^{56} \mathrm{Fe}<0\right)$, temporal variations in dust delivery should be correlated with $\delta^{56} \mathrm{Fe}$ values for the Central Pacific crust, but this is clearly not the case (Fig. 9). The uniformly low $\mathrm{Si}$ and $\mathrm{Al}$ contents (<1 wt. \%) in the crust 28DSR9 samples used for Fe isotope analysis indicates that bulk dust components did not contribute to the Fe isotope record. The constant $\mathrm{Pb}$ iso tope compositions for crust 28DSR9 over a wide range of dust delivery rates [41] (Fig. 9) may reflect a constant source for dust, or may indicate that the dissolved $\mathrm{Pb}$ flux to the deep Central Pacific Ocean was not strongly coupled to the amount of dust delivered to the surface ocean, as suggested by the 6-40 Ma Pb isotope record s of the $\mathrm{N}$ Pacific Ocean $[25,26]$. In the case of Fe- $\mathrm{Pb}$ isotope variations, the $\mathrm{Fe}$ and $\mathrm{Pb}$ isotope fingerprints of dust may be decoupled by uptake of $\mathrm{Fe}$ in the surface ocean through biological activity $[42,43]$. We therefore conclude that aeolian dust has had little influence on the deep ocean dissolved Fe budget recorded in the Central Pacific Ocean crust sample, at least not proportionally related to its flux at the surface ocean.

\subsection{Other continental sources of $F e$}

Chu et al., EPSL 
The two Izu-Bonin samples lie near the Western Pacific continental margin, suggesting that margin sediments or rivers may have been important sources of dissolved Fe at these locations. Reductive dissolution of continental shelf sediments may produce a significant flux of dis solved Fe to the oceans [e.g.44]. Reduction of reactive ferric Fe by dissimilatory iron-reducing bacteria (DIRB) may produce a significant flux of low- $\delta^{56} \mathrm{Fe} \mathrm{Fe}(\mathrm{II})_{\text {aq }}$ into the overlying water column, and $\delta^{56} \mathrm{Fe}$ values as low as $-3 \%$ are found in porewaters where DIRB drive signific ant $\mathrm{Fe}$ cycling in modern marine sediments off coastal California [45]. Although sulfide diagenesis may produce porewaters that have $\delta^{56} \mathrm{Fe}>0$ [45], the very low $\mathrm{Fe}(\mathrm{II})_{\text {aq }}$ contents in sulfide-dominated diagenetic systems excludes such components as a major con tributor to the Fe isotope compositions of the oceans. Dissolved loads of riverine input may carry low $\delta^{56} \mathrm{Fe}$ values, perhaps less than -1\%o [28], which could also account for the low $\delta^{56} \mathrm{Fe}$ values observed in the two Izu-Bonin crusts of this study $[12,13]$. Geochemical evidence, however, suggests that essentially all dissolved riverine $\mathrm{Fe}$ is scavenged in estuaries $[45,46]$ and is thus unlikely to contribute to the dis solved deep ocean Fe isotope bud get. If pore fluids from continental margin sediments and dissolved loads of rivers generally have low $\delta^{56} \mathrm{Fe}$ values (less than $-1 \%$ ), ferroman ganese crusts that have $\delta^{56} \mathrm{Fe}$ values between -1 and $0 \%$ may reflect mixtures between these low $-\delta^{56} \mathrm{Fe}$ sources and bulk detrital or aeolian sources that have $\delta^{56} \mathrm{Fe}$ values near zero [13].

\subsection{Hydrothermal sources for Fe}

The correlations between increasingly negative $\delta^{56} \mathrm{Fe}$ values and increases in $\mathrm{Mn}, \mathrm{Fe}, \mathrm{Mg}, \mathrm{Ni}, \mathrm{Cu}, \mathrm{Zn}, \mathrm{Mo}$, and V (Fig. 5) for the Izu-Bonin crust D97- 1 are interpreted to reflect pulses of hydrothermally-sourced Fe. Hydrothermal activity along the length of the Izu-Bonin Arc has been widespread over the last $10 \mathrm{Ma}$ [47-50] 
and the periods of negative $\delta^{56} \mathrm{Fe}$ excursions in crust D97-1 also correlate with rift-related volcanic activity that has been particularly active since about 3-4 Ma [51]. Hydrothermal fluids are enriched in $\mathrm{Fe}$ and $\mathrm{Mn}$, with concentrations six-fold higher than ambient seawater[52], although long-range transport of $\mathrm{Fe}$ is thought to be small from hydrothermal vents due to rapid oxidation and precipitation relative to $\mathrm{Mn}$ [53-58]. Mn enrichments in ferromanganese crusts have been previously interpreted to reflect pulses of increased hydrothermal in put [59], and the strong negative correlation of Fe isotope compositions and Mn content presented here supports this model. Elements such as $\mathrm{Mg}, \mathrm{Ni}, \mathrm{Zn}, \mathrm{Mo}$, and $\mathrm{V}$, are adsorbed preferentially onto Mn oxide phases $[60,61]$ and therefore also show strong negative correlations with $\delta^{56} \mathrm{Fe}$ in crust D97-1. The correlation between two stages of $\delta^{56} \mathrm{Fe}$ excursions to low values in crust D97-1 (before 3.7 Ma and at around $2 \mathrm{Ma}$ ) and high growth rates (Figs. $2 \& 3$ ) suggests that the increases in Mn content during these excursions may reflect increased metal uptake rates during periods of increased hydrothermal deposition.

If the above in terpretation is correct, an important question is why crust D105-5AB, which was collected $<100 \mathrm{~km}$ further north along the Izu-Bonin Arc, at a ca. $400 \mathrm{~m}$ shallower location, did not record the low- $\delta^{56} \mathrm{Fe}$ hydrothermal excursions that are observed in crust D97-1. One explanation could be the very short length-scales over which hydrothermal fluids are transported from any vent site to the surrounding water masses ( $\leq 10 \mathrm{~km}$ for dissolved Fe in the Pacific Ocean [62]). Perhaps equally important, however, is the depth difference between the two sites because sill depth for across-arc connection with the open Pacific Ocean lies between $1500 \mathrm{~m}$ and $2000 \mathrm{~m}$ in this region (Fig 1b). Strong lateral advection of currents across the top of the Izu-Bonin Arc may have led to greater homogenisation of the dissolved Fe-isotope record at the site of shallow crust D105-5AB (2120 m), whereas 
the deeper crust (D97-1, $2540 \mathrm{~m}$ ), which lies at $~ 500-1000 \mathrm{~m}$ below the across-axis sill depth, may have preferentially recorded input from deep-lying hydrothermal plumes. The distinct temporal variations in $\delta^{56} \mathrm{Fe}$ values between the two Izu-Bonin crusts highlight the extreme provinciality of Fe isotope compositions in the oceans, consistent with the short residence time of Fe.

The lowest $\delta^{56} \mathrm{Fe}$ values during the negative excursions in crust D97-1, down to $-0.95 \%$, are lower than any $\delta^{56} \mathrm{Fe}$ value so far measured from modern mid-ocean ridge (MOR) hydrothermal vents $[13,53,63]$, although that dataset is limited and does not include low-temperature diffusive-flow discharge. Levasseur et al. [12] measured a very low $\delta^{56} \mathrm{Fe}$ value $(-1.22 \%$ ) for a hydrothermal deposit on the Galapagos ridge, raising the possibility that MOR venting may produce a wider range of Fe isotope compositions that has yet to be directly measured. Severmann et al. [63] showed that the $\delta^{56} \mathrm{Fe}$ values for MOR hydrothermal fluids may remain constant over time periods up to 16,000 years, although it is unknown how this may vary over timescales of $1 \mathrm{Ma}$. In addition, because $>90 \%$ of dissolved Fe released from MOR vents is deposited proximal to the vent via rapid oxidation [54, 62], even small fluid-particulate $\mathrm{Fe}$ isotope fractionation factors may produce very low- $\delta^{56} \mathrm{Fe}$ values for the dissolved component at high degrees of precipitation. For example, assuming a modest $+0.1 \%$ fractionation between Fe precipitate and hydrothermal fluid $\mathrm{Fe}, 90$ $\%$ near-vent precipitation by Rayleigh fractionation would decrease the $\delta^{56} \mathrm{Fe}$ value of the remaining fluid by $0.23 \%$, and $99.9 \%$ precipitation would reduce the fluid by 0.69\% . These isotopic shifts would be superimposed upon the already moderately low $\delta^{56} \mathrm{Fe} \quad$ values measured in situ for hydrothermal vent fluids [12], producing a low- $\delta^{56} \mathrm{Fe}$ flux to the open oceans. We therefore contend that the low- $\delta^{56} \mathrm{Fe}$ values we interpret to reflect hydrothermally-sourced Fe are reasonable within the range 
expected to be produced during near-vent precipitation or those measured for hydrothermal deposits.

\section{Conclusions}

Our results from the Pacific Ocean give the first direct evidence that temporal $\mathrm{Fe}$ isotope variations may be distinct on a basin scale, even at distances of less than $100 \mathrm{~km}$. These results confirm the high degree of provinciality that is expected for Fe isotope variations in the modern oceans, reflecting the very short residence time of Fe. In a comparative study of two ferromanganese crusts from the Izu-Bonin basin, excursions to low $\delta^{56} \mathrm{Fe}$ values in one crust correlate with periods of increased crust growth and high concentrations of $\mathrm{Mn}$ and its uptake metals, including $\mathrm{Mg}, \mathrm{Ni}, \mathrm{Cu}$, $\mathrm{Zn}$, Mo, and V, reflecting pulses of hydrothermal venting that were intersected by one of the two crusts. Although the majority of the hydrothermal Fe flux to the open oceans is lost proximal to vents due to rapid oxidation of Fe, even small quantities of dissolved Fe that may be dispersed distal to the vent is apparently sufficient to be recorded in ferromanganese crusts, which grow on the order of $1-10 \mathrm{~mm} / \mathrm{Ma}$. The Fe isotope excursions recorded in Izu-Bonin crust D97-1 are therefore taken to reflect temporal changes in the intensity of hydrothermal activity at this specific location.

Moreover, we infer that $\delta^{56} \mathrm{Fe}$ values of hydrothermal Fe fluxes to the open oceans are less than or equal to those measured in situ at hydrothermal vents. Distinction between hydrothermal origins for low $\delta^{56} \mathrm{Fe}$ values in seawater and other low- $\delta^{56} \mathrm{Fe}$ sources should be possible through correlations with elements that are enriched in hydrothermal fluids, as observed in Izu-Bonin crust D97-1.

The time series for a ferromanganese crust from the Central Pacific Ocean is remarkably constant in Fe isotope compositions over the last $10 \mathrm{Ma}$ despite wide ranges in aeolian dust deposition in the surface ocean, suggesting that the deep oceans 
may have Fe sources and pathways that are distinct from those of the surface ocean.

There is no evidence that aeolian dust input, either through bulk (detrital) addition or partial dissolution by organic ligands, contributed Fe to the Central Pacific Ocean crust. Because all sources of dissolved Fe to the oceans appear to have negative $\delta^{56} \mathrm{Fe}$ values, including dissolved riverine input, pore waters from marine sediment diagenesis, partial dis solution of detrital Fe by organic ligands, and mid-ocean ridge (MOR) hydrothermal vent fluids, it is not yet clear if the moderately negative $\delta^{56} \mathrm{Fe}$ values recorded over the past $10 \mathrm{Ma}$ in the Central Pacific Ocean crust record an invariant balance of Fe sources, including hydrothermal vent fluids, or a single main source of Fe.

\section{Acknowledgments}

We thank P. Halbach for providing sample 28DSR9, D.R.H. Green for ICP-AES analyses, J.A. Milton for ICP-MS analyses, T. van de Flierdt for as sisting with high-resolution sampling, O. Ishizuka and G. Bayon for $\mathrm{Pb}$ isotopes analytical methods and discussions. We are grateful to the Worldwide University Network (WUN) exchan ge scholarship to N.C. in supporting the Fe isotope project. Two anonymous reviewers provided important comments that helped to sharpen the paper.

\section{References}

1 J.H. Martin, Glacial-interglacial CO2 chan ge: the iron hypothesis, Paleoceanography 5(1), 1-13, 1990.

2 P. Falkowski, Evolution of the nitrogen cycle and its influence on the biological sequestration of CO2 in the ocean, Nature 387(6630), 272-275, 1997.

3 T.D. Jickells and L.J. Spokes, Atmospheric Iron inputs to the oceans, in: The Biogeochemistry of Iron in Seawater, D.R. Turner and K.A. Hunter, eds., pp. 85-121, John Wiley \& Sons Ltd., 2001.

4 K.S. Johnson, R.M. Gordon and K.H. Coale, What controls dissolved iron concentrations in the world ocean?, Mar. Chem. 57(3-4), 137-161, 1997.

5 J. Wu, E. Boyle, W. Sunda and L.-S. Wen, Soluble and colloidal iron in the oligotrophic North Atlantic and North Pacific, Science 293(5531), 847-849, 2001. 
A. Laës, S. Blain, P. Laan, E.P. Achterberg, G. Sarthou and H.J.W. de Baar, Deep dissolved iron profiles in the eastern North Atlantic in relation to water masses, Geophys. Res. Lett. 30(17), 1902, 2003.

7 K.H. Coale, S.E. Fitzwater, R.M. Gordon, K.S. Johnson and R.T. Barber, Control of community growth and export production by upwelled iron in the equatorial Pacif ic Ocean, Nature 379, 621-624, 1996.

8 D.J. Mackey, J.E. O'Sullivan and R.J. Watson, Iron in the western Pacific: a riverine or hydrothermal source for iron in the Equatorial Undercurrent?, Deep Sea Research Part I: Oceanographic Research Papers(49), 877-893, 2002.

9 K.W. Bruland, K.J. Orians and J.P. Cowen, Reactive trace metals in the stratified central North Pacific, Geochim. Cosmochim. Acta 58(15), 3171-3182, 1994.

10 C.M. Johnson, B.L. Beard, E.E. Roden, D.K. Newman and K.H. Nealson, Isotopic constrain ts on biogeochemical cycling of $\mathrm{Fe}$, in: Reviews in Mineralogy and Geochemistry: Geochemistry of Non-Traditional Stable Isotopes 55, pp. 359-408, 2004.

11 X.K. Zhu, R.K. O'Nions, Y. Guo and B.C. Reynolds, Secular variation of iron isotopes in North Atlantic Deep Water, Science 287, 2000-2002, 2000.

12 S. Levasseur, M. Frank, J.R. Hein and A.N. Halliday, The global variation in the iron isotope composition of marine hydrogenetic ferromanganese deposits: implications for seawater chemistry?, Earth Planet. Sci. Lett. 224(1-2), 91-105, 2004.

13 B.L. Beard, C.M. Johnson, K.L. Von Damm and R.L. Poulson, Iron isotope constrains on Fe cycling and mass balance in oxygenated Earth oceans, Geology 31(7), 629-632, 2003.

14 I. Livingstone and A. Warren, Aeolian Geomorphology: An Introduction, 1083-1084 pp., Longman, 1996.

15 A. Koschinsky, A. Stascheit, M. Bau and P. Halbach, Effects of phosphatization on the geochemical and mineralogical composition of marine ferromanganese crusts, Geochim. Cosmochim. Acta 61(19), 4079-4094, 1997.

16 W.U. Henken-Mellies, J. Beer, F. Heller, K.J. Hsu, C. Shen, G. Bonani, H.J. Hofmann, M. Suter and W. Wolfli, 10Be and 9Be in South Atlantic DSDP Site 519: Relation to geomagnetic reversals and to sediment composition, Earth Planet. Sci. Lett. 98(3-4), 267-276, 1990.

17 B.L. Beard, C.M. Johnson, J.L. Skulan, K.H. Nealson, L. Cox and H. Sun, Application of $\mathrm{Fe}$ isotopes to tracing the geochemical and biological cycling of Fe, Chem. Geol. 195, 87-117, 2003.

18 O. Ishizuka, R.N. Taylor, J.A. Milton and R.W. Nesbitt, Fluid-mantle interaction in an intra-oceanic arc: constraints from high-precision $\mathrm{Pb}$ isotopes, Earth Planet. Sci. Lett. 211(3-4), 221-236, 2003.

19 N.S. Belshaw, P.A. Freedman, R.K. O'Nions, M. Frank and Y. Guo, A new variable dispersion double-focusing plasma mass spectrometer with performance illustrated for $\mathrm{Pb}$ isotopes, Int. J.Mass Spectrom. 181, 51-58, 1998.

20 P. Halbach, U. Hebisch and C. Scherhag, Geochemical variations of ferromanganese nodules and crusts from different provinces of the Pacific Ocean and their genetic control, Chem. Geol. 34, 3-17, 1981.

21 A. Usui and M. Someya, Distribution and composition of marine hydrogenetic and hydrothermal manganese deposits in the northwest Pacific, in: Manganese Mineralization: Geochemistry and Mineralogy of Terrestrial and Marine 
Deposits, K. Nicholson, J.R. Hein, B. Bühn and S. Dasgupta, eds., Geological Society Special Publication No. 119, pp. 177-198, The Geological Society, London, 1997.

22 N.-C. Chu, An investigation into $\mathrm{Hf}$ and Fe Isotopes in ferromanganese deposits and their applications to paleoceanography, University of Southampton, 2004.

23 J.N. Christensen, A.N. Halliday, L.V. Godfrey, J.R. Hein and D.K. Rea, Climate and ocean dynamics and the lead isotopic records in Pacific ferromanganese crusts, Science 277, 913-918, 1997.

24 H.F. Ling, K.W. Burton, R.K. O'Nions, B.S. Kamber, F. von Blanckenburg, A.J. Gibb and J.R. Hein, Evolution of $\mathrm{Nd}$ and $\mathrm{Pb}$ isotopes in Central Pacific seawater from ferromangan ese crusts, Earth Planet. Sci. Lett. 146, 1-12, 1997.

25 H.-F. Ling, S.-Y. Jiang, M. Frank, H.- Y. Zhou, F. Zhou, Z.-L. Lu, X.-M. Chen, Y.-H. Jiang and C.-D. Ge, Differing controls over the Cenozoic $\mathrm{Pb}$ and $\mathrm{Nd}$ isotope evolution of deepwater in the central North Pacific Ocean, Earth Planet. Sci. Lett. 232(3-4), 345-361, 2005.

26 T. van de Flierdt, M. Frank, A.N. Halliday, J.R. Hein, B. Hattendorf, D. G ther and P.K. Kubik, Lead isotopes in North Pacific deep water - implications for past changes in input sources and circulation patterns, Earth Planet. Sci. Lett. 209(1-2), 149-164, 2003.

27 C.M. Johnson, B.L. Beard, N.J. Beukes, C. Klein and J.M. O'Leary, Ancient geochemical cycling in the Earth as inferred from Fe isotope studies of banded iron formation s from the Transvaal Craton, Contrib. Mineral. Petrol. 144, 523-547, 2003.

28 M.S. Fantle and D.J. DePaolo, Iron isotopic fractionation during continental weathering, Earth Planet. Sci. Lett. 228(3-4), 547-562, 2004.

29 D.J. DePaolo, Trace element and isotopic effects of combined wallrock assimilation and fractional crystallization, Earth Planet. Sci. Lett. 53(2), 189-202, 1981.

30 M. Rehkämper, M. Frank, J. Hein, D. Porcelli, A.N. Halliday, J. Ingri and V. Liebetrau, Thallium isotope variations in seawater and hydrogenetic, diagenetic, and hydrothermal ferromangan ese deposits, Earth Planet. Sci. Lett. 197(1-2), 65-81, 2002.

31 C. Siebert, T.F. Nägler, F. von Blanckenburg and J.D. Kramers, Molybdenum isotope records as a potential new proxy for paleoceanography, Earth Planet. Sci. Lett. 211, 159-171, 2003.

32 J.L. Skulan, B.L. Beard and C.M. Johnson, Kinetic and equilibrium Fe iso tope fractionation between aqueous Fe(III) and hematite, Geochim. Cosmochim. Acta 66(17), 2995-3015, 2002.

33 F.J. Millero, Speciation of metals in natural waters, Geochem. Trans. 8, 2001.

34 C.M.G. van den Berg, Evidence for organic complexation of iron in seawater, Marine Chemistry 50(1-4), 139-157, 1995.

35 S.L. Brantley, L.J. Liermann, R.L. Guynn, A. Anbar, G.A. Icopini and J. Barling, Fe isotopic fractionation during mineral dissolution with and without bacteria, Geochim. Cosmochim. Acta 68(15), 3189-3204, 2004.

36 C.E. Jones, A.N. Halliday, D.K. Rea and R.M. Owen, Eolian input of lead to the North Pacific, Geochim. Cosmochim. Acta 64(8), 1405-1416, 2000.

37 L.V. Godfrey, Temporal changes in the lead iso topic compsition of read clays: comparison with ferromanganese crust records, Chem. Geol 185, 241-254, 2002 . 
T. Pettke, A.N. Halliday, C.M. Hall and D.K. Rea, Dust production and deposition in Asia and the north Pacific Ocean over the past 12 Myr, Earth Planet. Sci. Lett. 178, 397-413, 2000.

39 T. van de Flierdt, M. Frank, A.N. Halliday, J.R. Hein, B. Hattendorf, D. Gunther and P.W. Kubik, Tracing the history of submarine hydrothermal inputs and the significance of hydrothermal hafnium for the seawater budget-a combined Pb-Hf-Nd iso tope approach, Earth Planet. Sci. Lett. 222(1), 259-273, 2004.

40 R.A. Duce and N.W. Tindale, Atmospheric tran sport of iron and its deposition in the ocean, Limnol. Oceanogr. 36(8), 1715-1726, 1991.

41 D.K. Rea, The paleoclimatic record provided by eolian deposition in the deep sea: the geologic history of wind, Rev. Geoph ys. 32(2), 159-195, 1994.

42 J.H. Martin, K.H. Coale, K.S. Johnson, S.E. Fitzwater, R.M. Gordon, S.J. Tanner, C.N. Hunter, V.A. Elrod, J.L. Nowicki, T.L. Coley, R.T. Barber, S. Lindley, A.J. Watson, K. Vanscoy, C.S. Law, M.I. Liddicoat, R. Ling, T. Stanton, J. Stockel, C. Collins, A. Anderson, R. Bidigare, M. Ondrusek, M. Latasa, F.J. Millero, K. Lee, W. Yao, J.Z. Zhang, G. Friedrich, C. Sakamoto, F. Chavez, K. Buck, Z. Kolber, R. Greene, P. Falkowski, S.W. Chisholm, F. Hoge, R. Swift, J. Yungel, S. Turner, P. Nightingale, A. Hatton, P.S. Liss and N.W. Tindale, Test the iron hypothesis in ecosystems of the equatorial Pacific-Ocean, Nature 371, 123-129, 1994.

43 K.H. Coale, K.S. Johnson, S.E. Fitzwater, R.M. Gordon, S.J. Tanner, F.P. Chavez, L. Ferioli, C. Sakamoto, P. Rogers, F.J. Millero, P. Steinberg, P. Nightingale, D. Cooper, W.P. Cochlan, M.R. Landry, J. Constantinou, G. Rollwagen, A. Trasvina and R. Kudela, A massive phytoplankton bloom induced by an ecosystem-scale iron fertilization experiment in the equatorial Pacific Ocean, Nature 383(6600), 495-501, 1996.

44 H.J.W. de Baar and J.T.M. de Jong, Distribtions, sources and sinks of iron in seawater, in: The Biogeochemistry of Iron in Seawater, D.R. Turner and K.A. Hunter, eds., IUPAC series on analytical and physical chemistry of environmental systems ; v. 7, pp. 123-253, John Wiley \& Sons Ltd., 2001.

45 E.A. Boyle and J.M. Edmond, The mechanism of iron removal in estuaries, Geochim. Cosmochim. Acta 41(9), 1313-1324, 1977.

46 E.R. Sholkovitz and D. Copland, The coagulation, solubility and ad sorption properties of $\mathrm{Fe}, \mathrm{Mn}, \mathrm{Cu}, \mathrm{Ni}, \mathrm{Cd}, \mathrm{Co}$ and humic acid in a river water, Geochim. Cosmochim. Acta 45(2), 181-189, 1981.

47 K. Iizasa, R.S. Fiske, O. Ishizuka, M. Yuasa, J. Hashimoto, J. Ishibashi, J. Naka, Y. Horii, Y. Fujiwara, A. Imai and S. Koyama, A Kuroko-type polymetallic sulfide deposit in a submarine silic ic caldera, Science 283, 975-977, 1999.

48 T. Urabe and M. Kusakabe, Barite silica chimneys from the Sumisu Rift, Izu-Bonin Arc: possible analog to hematitic chert associated with Kuroko deposits, Earth Planet. Sci. Lett. 100, 283-290, 1990.

49 U. Tsunogai, J. Ishibashi, H. Wakita, T. Gamo, K. Watanabe, T. Kajimura, S. Kanayama and H. Sakai, Peculiar features of Suiyo Seamount hydrothermal fluids, Imu-Bonin Arc: Differences from subaerial volcanism, Earth Planet. Sci. Lett. 126(4), 289-301, 1994.

50 O. Ishizuka, M. Yuasa and K. Uto, Evidence of porphyry copper-type hydrothermal activity from a submerged remnant back-arc volcano of the 
Izu-Bonin arc; implications for the volcanotectonic history of back-arc seamounts, Earth Planet. Sci. Lett. 198, 381-399, 2002.

51 O. Ishizuka, K. Uto and M. Yuasa, Volcanic history of the back-arc region of the Izu-Bonin (Osagawara) arc, in: Intra-oceanic subduction systems: tectonic and magmatic processes, R.D. Larter and P.T. Leat, eds., Geological Society, London, Special Publications 219, pp. 187-205, The Geological Society of London, 2003.

52 C.R. German and K.L. Von Damm, Hydrothermal Processes, in: The Ocean s and Marine Chemistry, H. Elderfield, ed., Treatise on Geochemistry 6, Elsevier, Oxford, 2003.

53 M. Sharma, M. Polizzotto and A.D. Anbar, Iron isotopes in hot springs along the Juan de Fuca Ridge, Earth Planet. Sci. Lett. 194, 39-51, 2001.

54 P.J. Statham, C.R. German and D.P. Connelly, Iron (II) distribution and oxidation kinetics in hydrothermal plumes at the Kairei and Edmond vent sites, Indian Ocean, Earth Planet. Sci. Lett. 236(3-4), 588-596, 2004.

55 R.A. Feely, T.L. Geiselman, E.T. Baker, G.J. Massoth and S.R. Hammond, Distribution and composition of buoyant and non-buoyant hydrothermal plume particles from the ASHES vent at Axial Volcano, Juan de Fuca Ridge, J. Geophys. Res. 95, 12855-12874, 1990.

56 M.D. Rudnicki and H. Elderfield, A chemical model of the buoyant and neutrally buoyant plume above the TAG vent field, 26 degree N, Mid-Atlantic Ridge, Geochim. Cosmochim. Acta 57(13), 2939-2957, 1993.

57 G.J. Massoth, E.T. Baker, R.A. Feely, J.E. Lupton, R.W. Collier, J.F. Gendron, K.K. Roe, S.M. Maenner and J.A. Resing, Manganese and iron in hydrothermal plumes resulting from the 1996 Gorda Ridge Event, Deep Sea Research Part II: Topical Studies in Oceanography 45(12), 2683-2712, 1998.

58 J.P. Cowen, G.J. Massoth and R.A. Feely, Scavenging rates of dissolved man ganese in a hydrothermal vent plume, Deep Sea Res. I 37, 1619-1637, 1990.

59 C. Lalou, Genesis of ferromanganese deposits: hydrothermal origin, in: Hydrothermal processes at seafloor spreading centres, P. Rona, K. Bostrom, L. Laubier and K.L. Smith, eds., pp. 503-534, Plenum Press, New York, 1983.

60 A. Koschinsky, M. Van Gerven and P. Halbach, First investigations of massive ferroman ganese crusts in the NE Atlantic in comparison with hydrogenetic Pacific occurrences, Mar. Geores. and Geotech. 13, 375-391, 1995.

61 A. Koschinsky and J.R. Hein, Uptake of elements from seawater by ferromanganese crusts: solid-phase associations and seawater speciation, Mar. Geol. 198, 331-351, 2003.

62 M.P. Field and R.M. Sherrell, Dissolved and particulate Fe in a hydrothermal plume at $9^{\circ} 45^{\prime} \mathrm{N}$, East Pacific Rise: Slow Fe(II) oxidation kinetics in Pacific plumes, Geochim. Cosmochim. Acta 64(4), 619-628, 2000.

63 S. Severmann, C.M. Johnson, B.L. Beard, C.R. German, H.N. Edmond, H. Chiba and D.R.H. Green, The effect of plume processes on the Fe isotope composition of hydrothermally derieved $\mathrm{Fe}$ in the deep oceans as inferred from the Rainbow vent site, Mid-Atlantic Ridge, $36^{\circ} 14^{\prime} \mathrm{N}$, Earth Planet. Sci. Lett. 225(1-2), 63-76, 2004.

64 L.A. Kris sek and T.R. Janecek, Eolian deposition on the Ontong Java Plateau since the oligocene: unmixing a record of multiple dust source, in: Proceeding of the Ocean Drilling Program, Scientific Results, W.H. Berger, L.W. Kroenke 
and L.A. Mayer, eds. 130, pp. 471-490, College Station, TX (Ocean Drilling Program), 1993.

65 F. Rack, T.R. Janecek, E. Erba, J. Fenner and J.S. Gee, Syn thesis of terrigenous accumulation rates and biostratigraphic studies at sites in the northwestern Pacific Ocean, with comparisons to adjacent regions of the Pacific Gyre, in: Proceedings of the Ocean Drilling Program, Scientific Results, J.A. Haggerty, I. Premoli Silva, F. Rack and M.K. McNutt, eds. 144, pp. 691-736, College Station, TX (Ocean Drilling Program), 1995.

66 S.R. Hart, A large-scale isotopic anomaly in the southern hemisphere mantle, Nature 309, 753-757, 1984.

\section{Figure Captions}

\section{Figure 1.}

(a) Sample locations and (b) bathymetric map of Izu-Bonin back-arc basin showing the three Ferromanganese crusts from this study: D105-5AB, D97-1, and 28DSR9. Two related locations are additionally marked: (1) two ODP TMAR records at site 803 [64] and site 871 [65] and (2) Fe-Mn crust from the North Atlantic Ocean (BM1969.05) that Zhu et al. [11] have previously studied for temporal Fe isotope variations. Modern dust source regions and wind trajectories [14] are labelled in grey shaded areas and solid arrows. In the bathymetric map, the dashed line represents the modern volcanic front, and the current back-arc rift zone lies immediately west. The two Izu-Bonin samples analysed in this study are marked by open and solid triangles, and are situated on the western flanks of the current back-arc rift zone.

\section{Figure 2.}

Calculated age and ${ }^{10} \mathrm{Be} /{ }^{9} \mathrm{Be}$ versus depth for crusts 28DSR9, D105-5AB, and D97-1. Ages have been calculated using a half-life of $1.5 \mathrm{Myr}$ for ${ }^{10} \mathrm{Be}$, and assuming that the

${ }^{10} \mathrm{Be} /{ }^{9} \mathrm{Be}$ ratio has been constant at the growth surfaces of the crusts. Growth rates $(\mathrm{mm} / \mathrm{Ma})$ were determined by the best fit regression slopes for the marked line segments.

\section{Figure 3.}


Temporal variations in $\delta^{56} \mathrm{Fe}$ values for crusts 28DSR9, D105-5AB, and D97-1, represented as solid squares, open triangles and solid triangles, respectively. Ages for individual layers based on ${ }^{10} \mathrm{Be} /{ }^{9} \mathrm{Be}$ chronology (Fig. 2). Error bars for the Pacific crusts of this study are 1SD (external) for replicate analyses or 2SE (internal) for $\delta^{56} \mathrm{Fe}$ for single an alyses of layers.

\section{Figure 4.}

Temporal variations in element abundances ( $\mathrm{Mn}, \mathrm{Fe}, \mathrm{Ca}, \mathrm{Zn}, \mathrm{Ni}$, and $\mathrm{Mg}$ ) throughout crusts 28DSR9 (solid squares), D105-5AB (open triangles), and D97-1 (solid triangles). Note that element concentrations were determined on an order of magnitude larger-sized solid powders than those used for Fe isotope analyses. Average $2 \mathrm{SD}$ error for $\delta^{56} \mathrm{Fe}$ values shown; elemental contents precise to $\pm 1 \%$. Symbols as in Fig. 3.

\section{Figure 5.}

Element- $\delta^{56} \mathrm{Fe}$ correlations of different growth layers on the three crust samples. Correlation lines and coefficients $\left(\mathrm{R}^{2}\right)$ for D97-1 layers are marked. Symbols as in Fig. 3.

\section{Figure 6.}

Comparison of temporal variations in Fe isotope compositions and (a) elements or (b) $\mathrm{Fe} / \mathrm{Mn}$ and $\mathrm{Co} / \mathrm{Mn}$ ratios in crust D97-1, as determined by ICP-AES analysis of bulk powders (open circles) and EPMA (grey solid lines) profiles of Mn, Fe and Ti. Note the reversed Mn scale. Elemental abund ances and weight ratios are shown on the left axis and $\delta^{56} \mathrm{Fe}$ values (filled triangles) are shown on the right axis.

\section{Figure 7.}

Variations among $\mathrm{Pb}$ and $\mathrm{Fe}$ isotope compositions for the three crusts of this study. Because Fe isotope compositions were determined on different layers as those 
analyzed for $\mathrm{Pb}$ isotopes, $\delta^{56} \mathrm{Fe}$ values were interpolated based on temporal variations shown in Fig. 3. The estimated uncertainty in this interpolation is at most $0.3 \%$ o (marked on the figure). North Hemisphere Reference Line (NHRL) is defined by MORB and OIB data [66]. Volcanic and sediment data were compiled from literatures (see [22]).

\section{Figure 8 .}

Flow-through box model showing the effect of Fe residence time and isotopic fractionation upon precipitation of $\mathrm{Fe}-\mathrm{Mn}$ crust relative to $\delta^{56} \mathrm{Fe}$ values in the $\mathrm{Fe}-\mathrm{Mn}$ crusts. The incoming flux $\delta^{56} \mathrm{Fe}$ value $\left(\delta_{\text {IN }}\right)$ is assumed to be $-1 \%$ and $\Delta_{\text {crust-SW }}=$ $+1 \%$. (a) Illustration of box model, where the box reflects an arbitrary seawater volume through which Fe passes prior to precipitation of ferromanganese crust. The flux in $\left(\mathrm{J}_{\mathrm{IN}}\right)$ is assumed to be equal to the outgoing flux ( $\left.\mathrm{J}_{\mathrm{OUT}}\right)$, and the partition coefficient between crust and seawater (D) determines the Fe residence time $(\tau)$. See text for detailed description of variables and assumptions. (b) Calculated $\delta^{56} \mathrm{Fe}$ of precipitated crusts (solid lines) and seawater reservoir adjacent to crust (dashed lines) through increasing incoming flux at short (black) and long (grey) residence times, relative to the integrated mass ratio of the incoming flux $\left(\mathrm{M}_{\mathrm{IN}}\right)$ relative to the immediate seawater reservoir (Msw) (grey box volume in (a)).

\section{Figure 9.}

Terrestrial Mass Accumulation Rate (MAR) records at adjacent locations ([64, 65], see Fig. 1 for location) compared to temporal variations in $\mathrm{Fe}$ and $\mathrm{Pb}$ isotope compositions of the Central Pacific sample (28DSR9). 
(a)

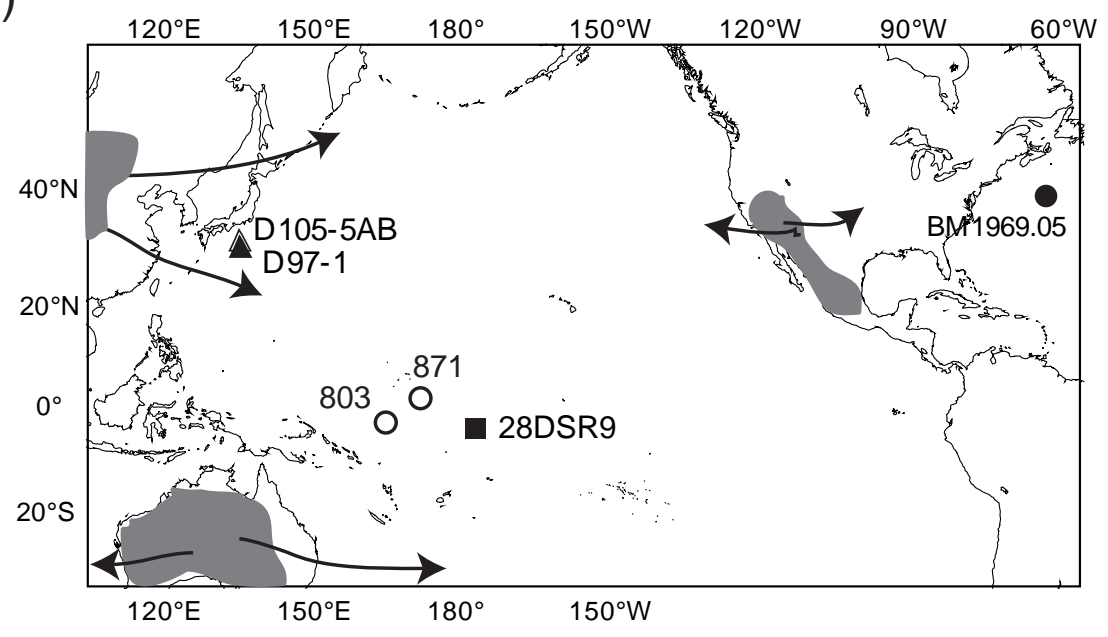

(b)

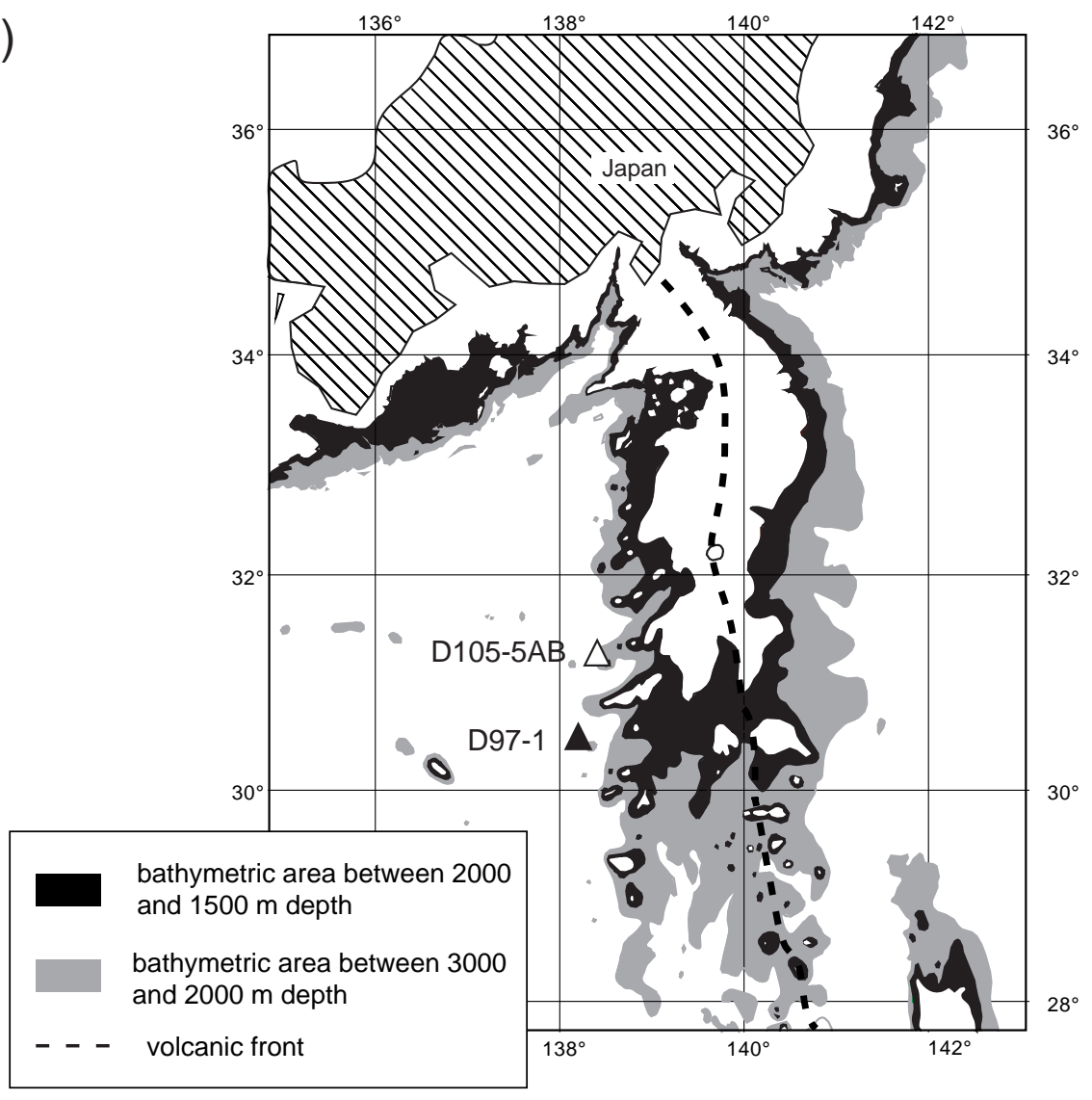


Fig. 2_Chu et al.
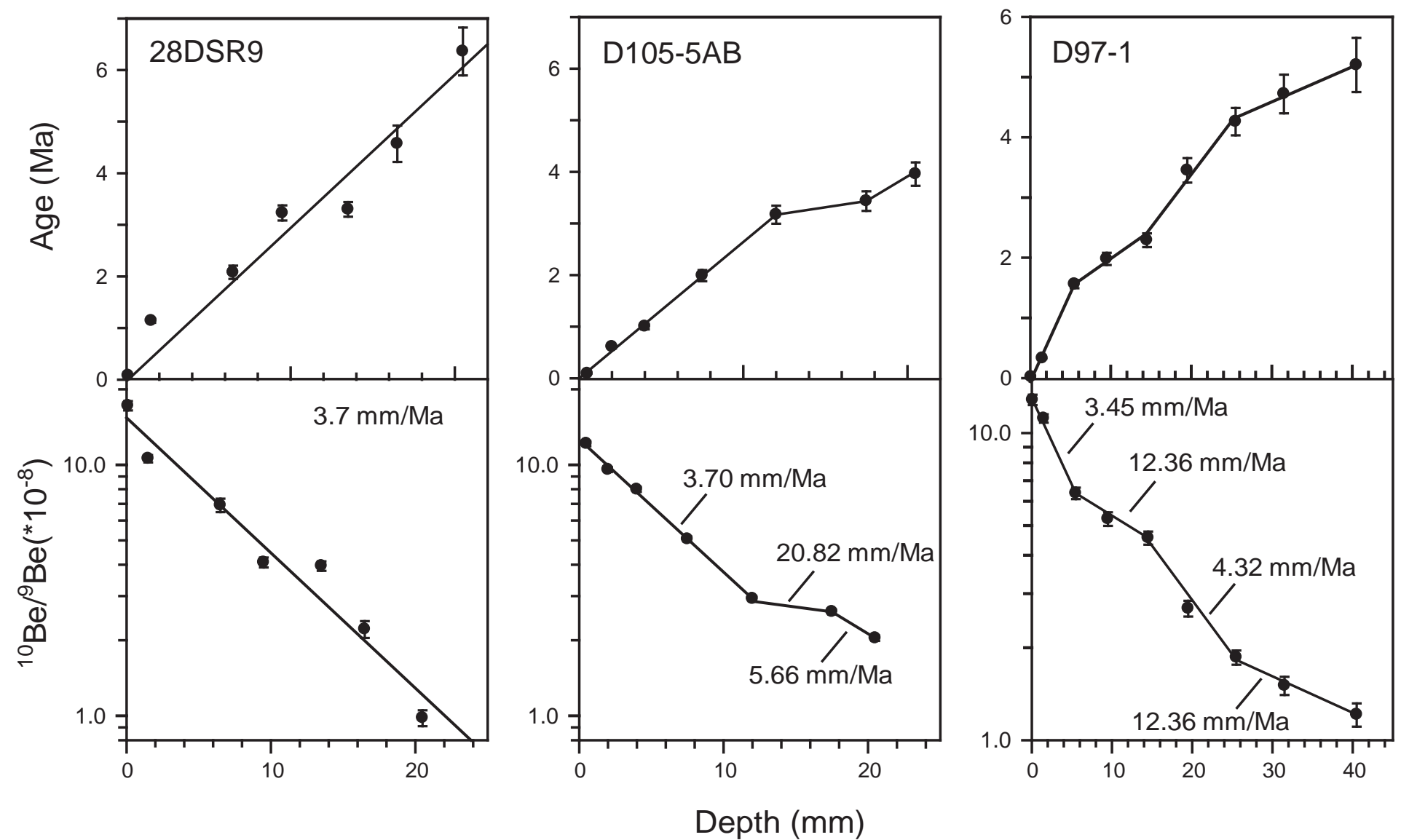

Depth (mm) 
Fig.3_Chuet al.

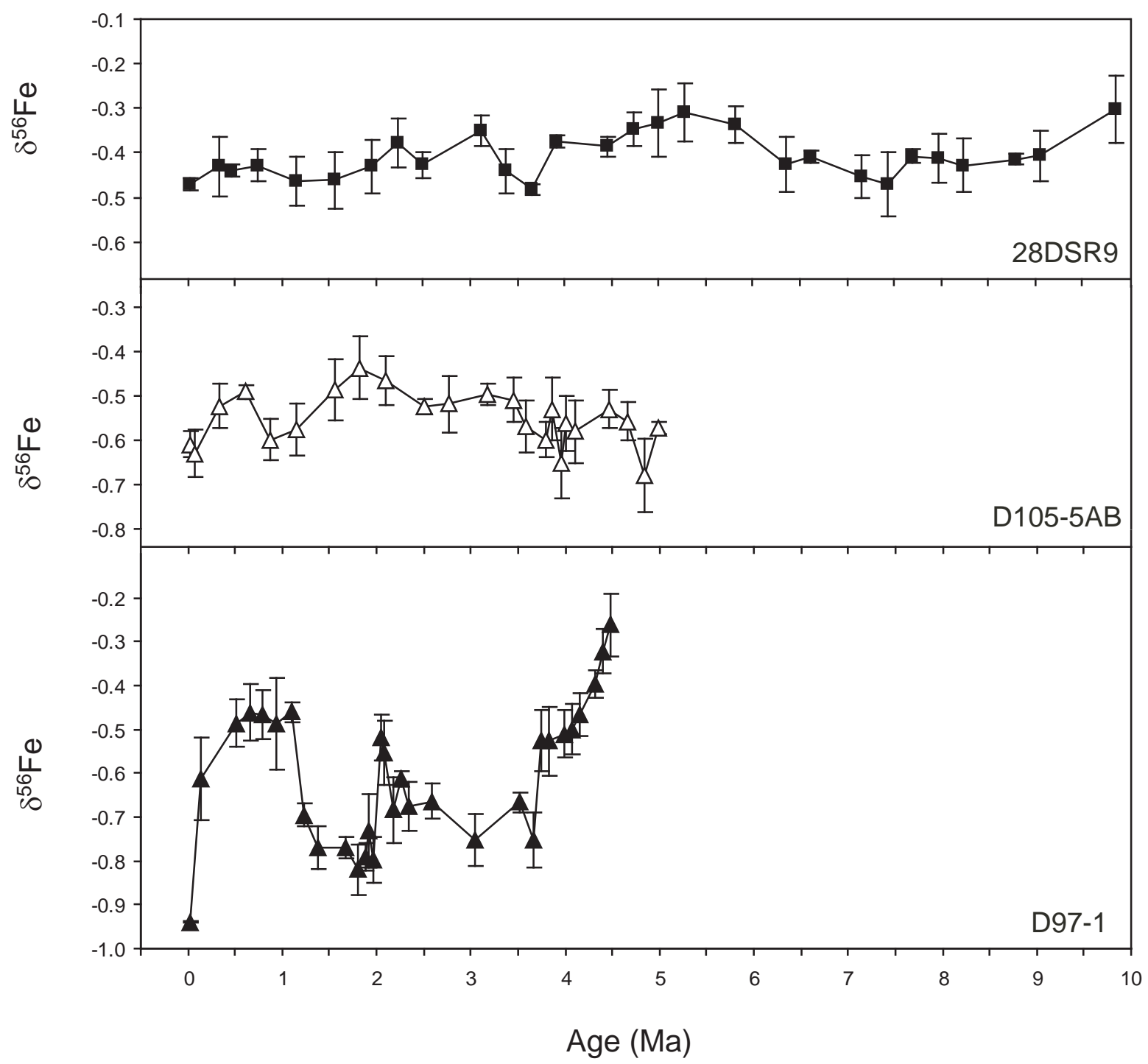


Fig. 4_Chuetal.
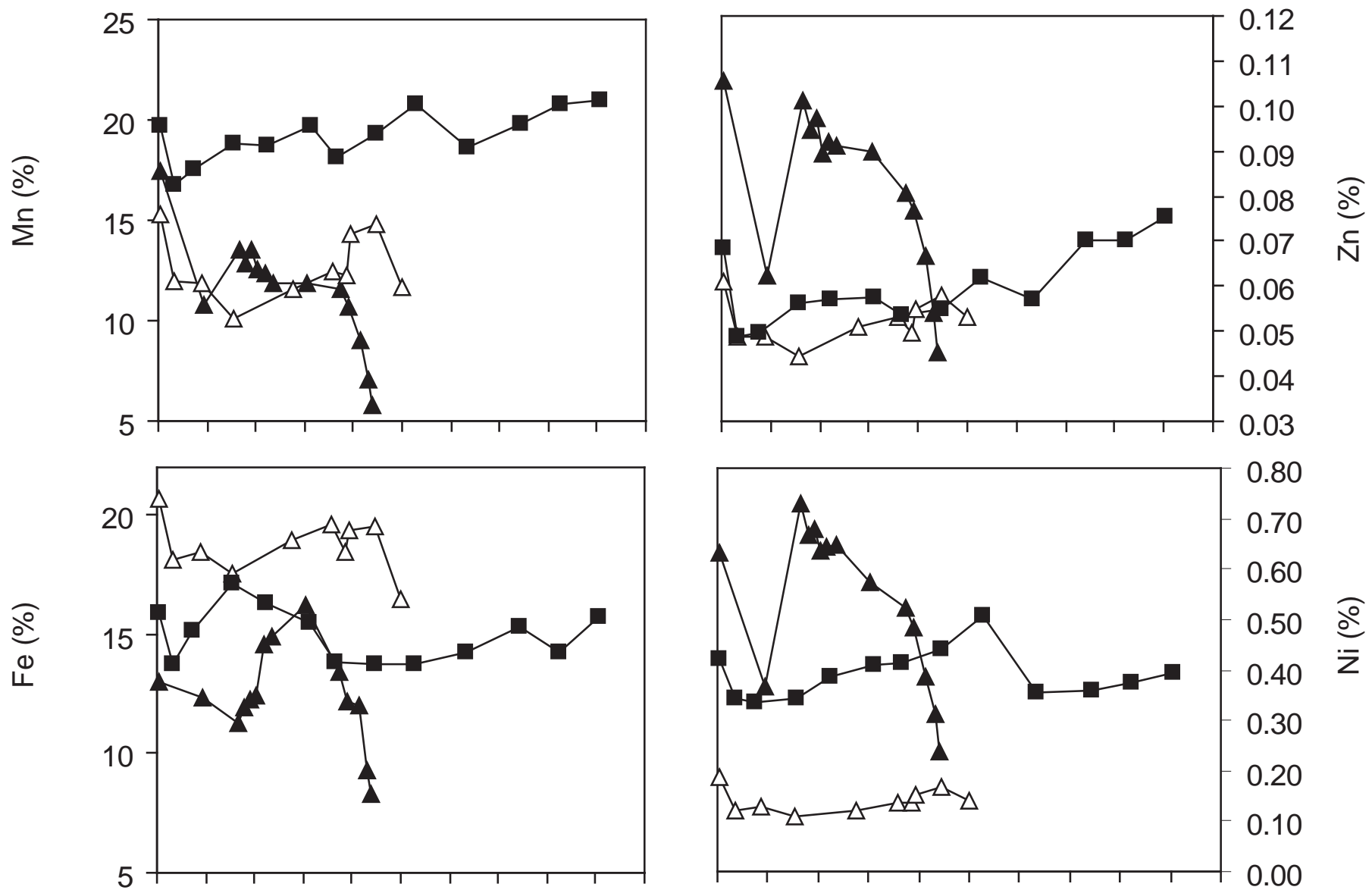

0.80

0.70

0.60

0.50

$\frac{\mathfrak{d}}{z}$
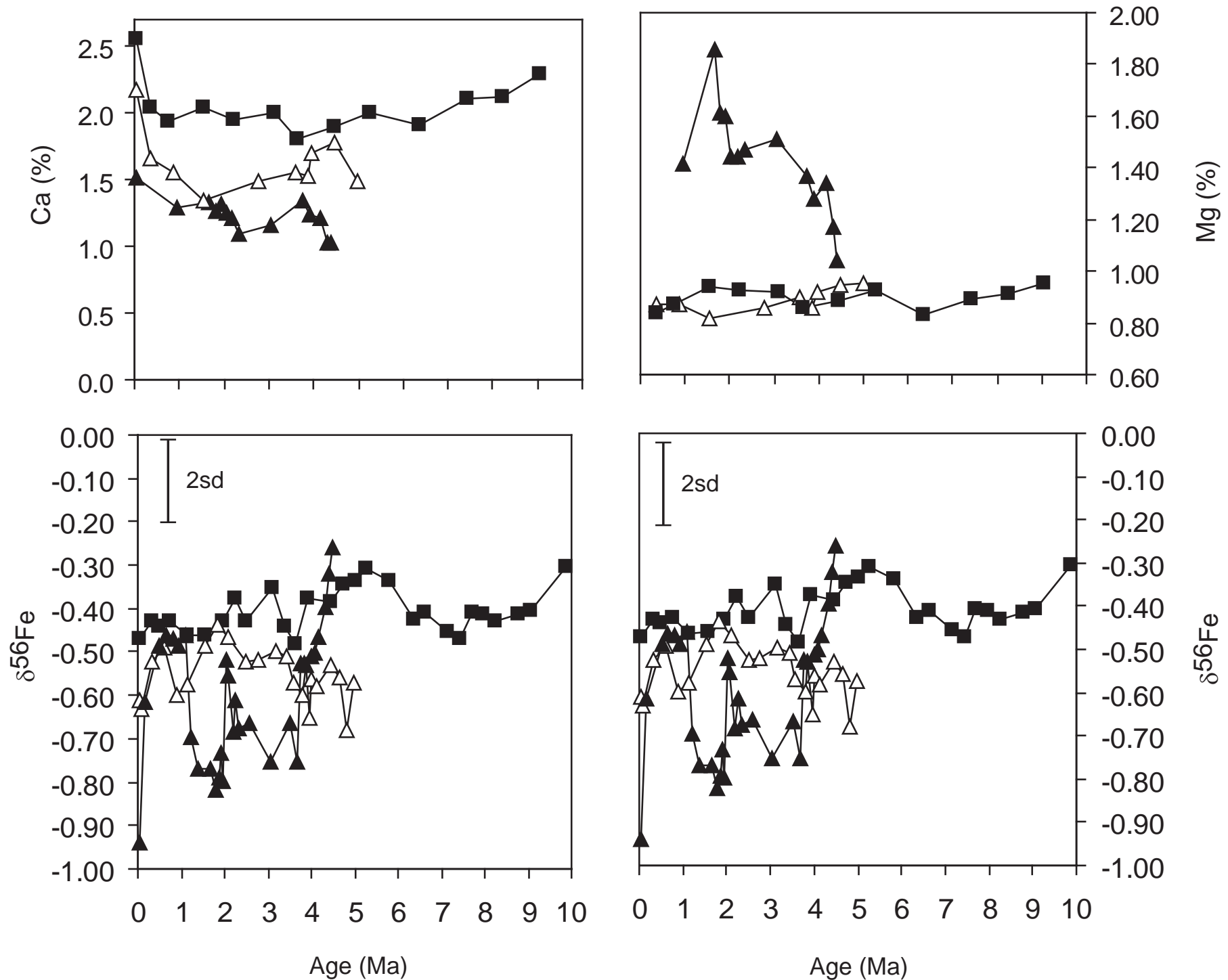
Fig. 5_Chuetal.
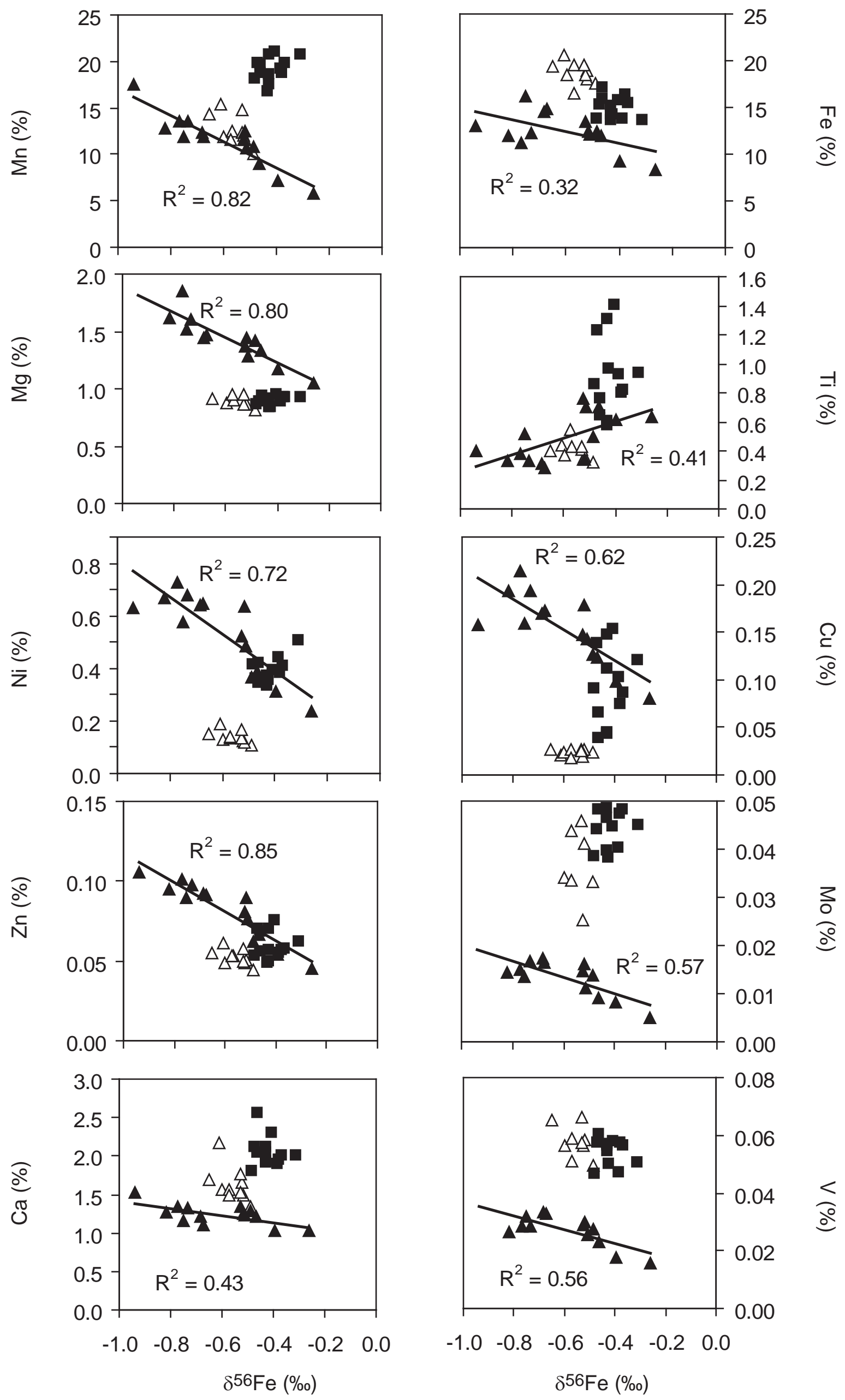

$\begin{array}{llllll}-1.0 & -0.8 & -0.6 & -0.4 & -0.2 & 0.0\end{array}$ $\delta^{56} \mathrm{Fe}(\%)$ 
Fig. 6_Chu et al.

(a)

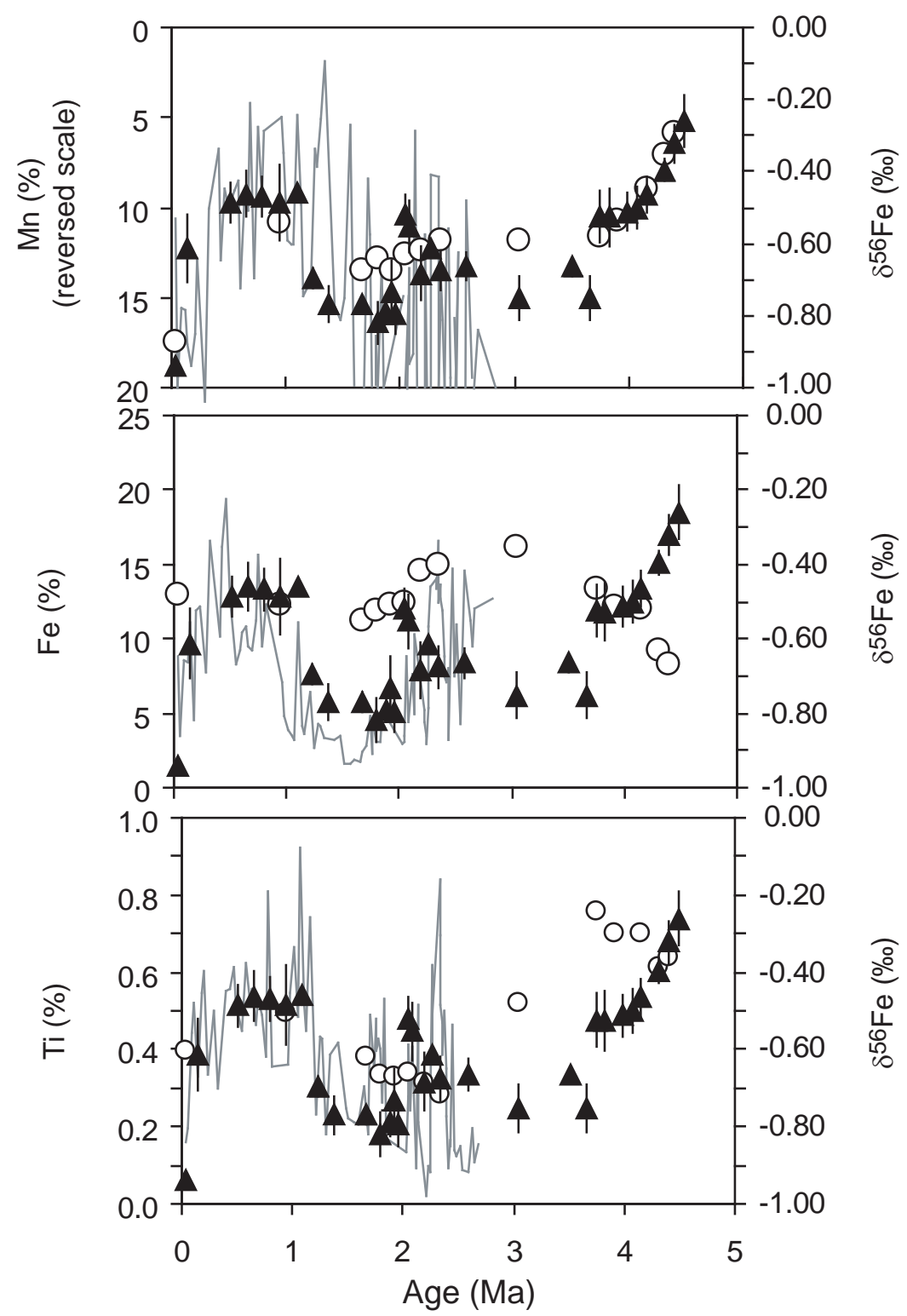

(b)

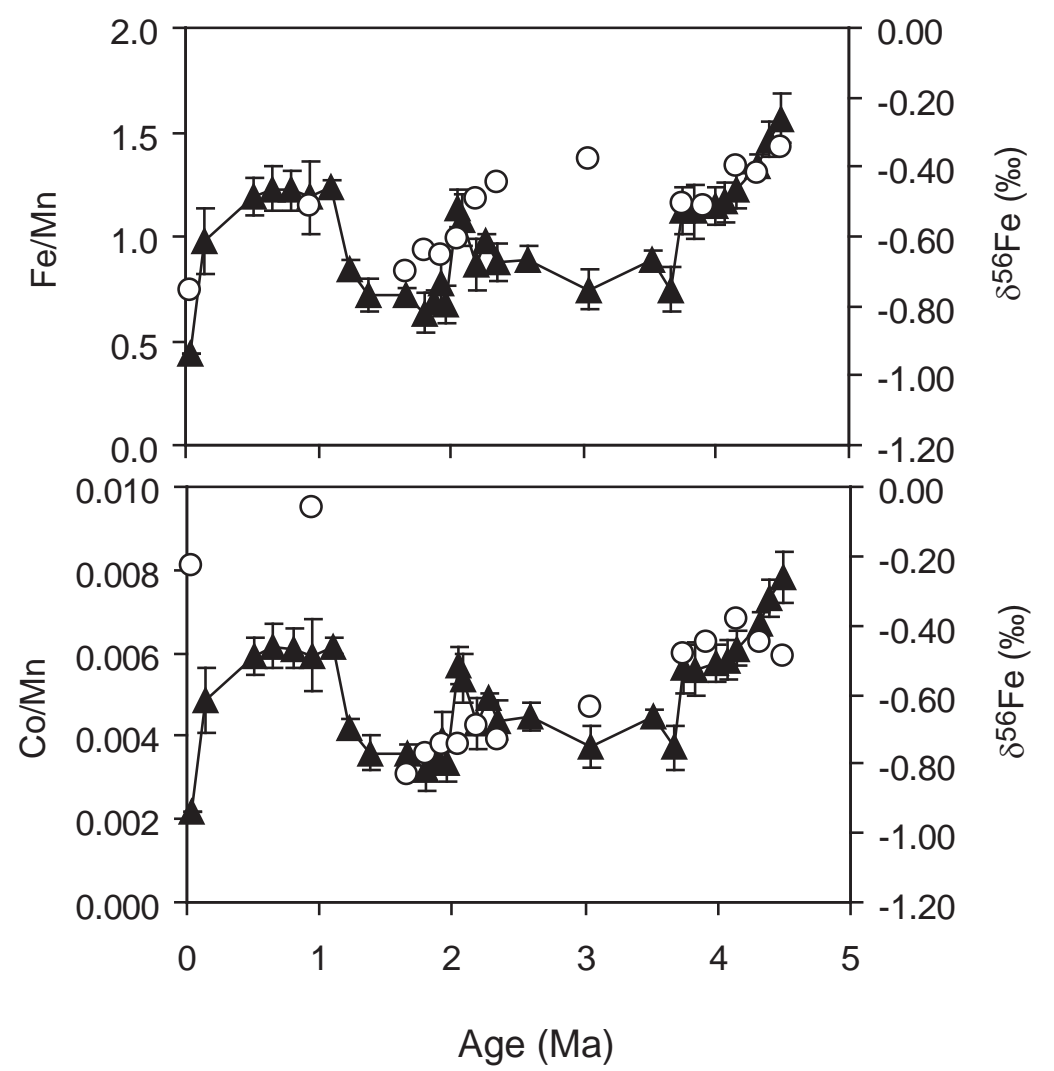




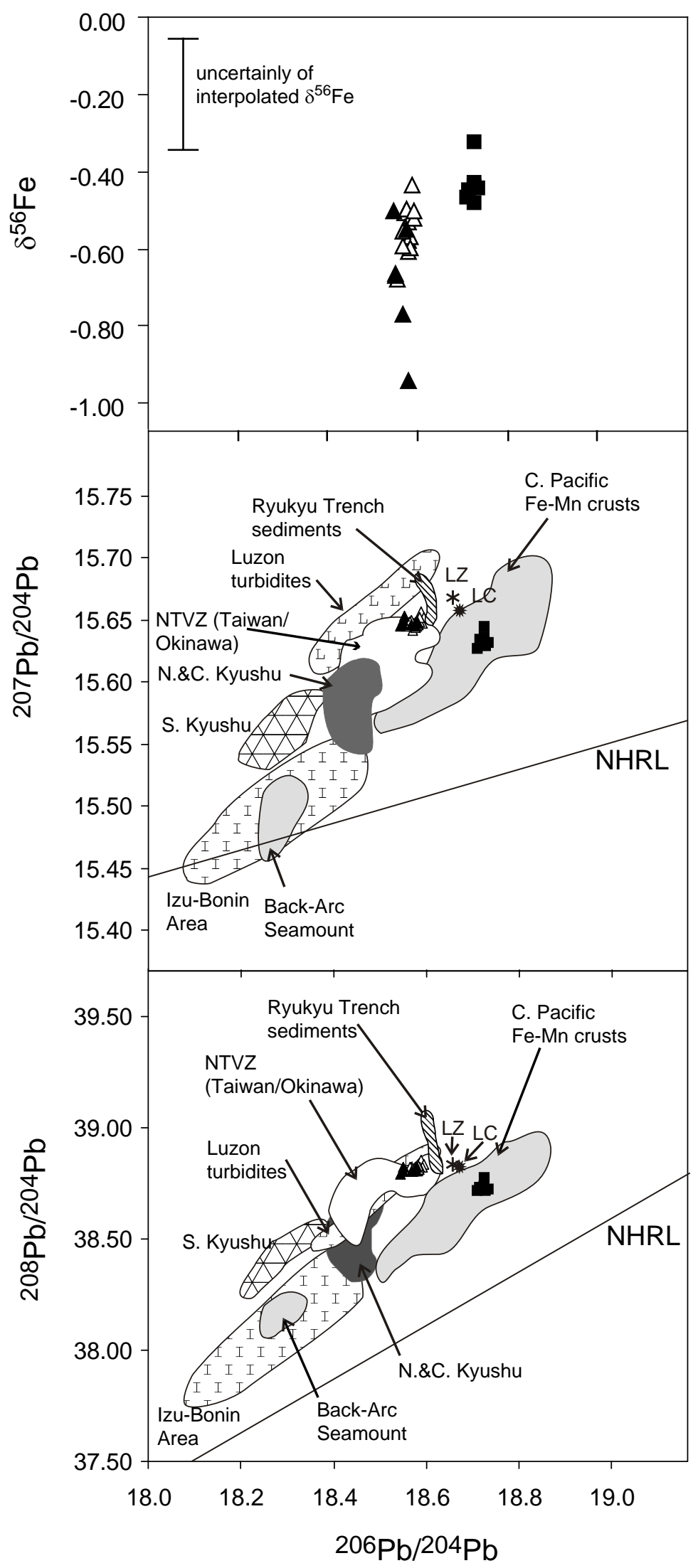

* Lanzhou Loess (LZ)

* Luochuan Loess (LC)

$\mathrm{NHRL}=\mathrm{MORB}+\mathrm{OIB}$

Fe-Mn crusts (this study)

$\triangle \mathrm{D} 105-5 \mathrm{AB}$

$\Delta$ D97-1

- 28DSR9 
Fig. 8_Chu etal.

(a)

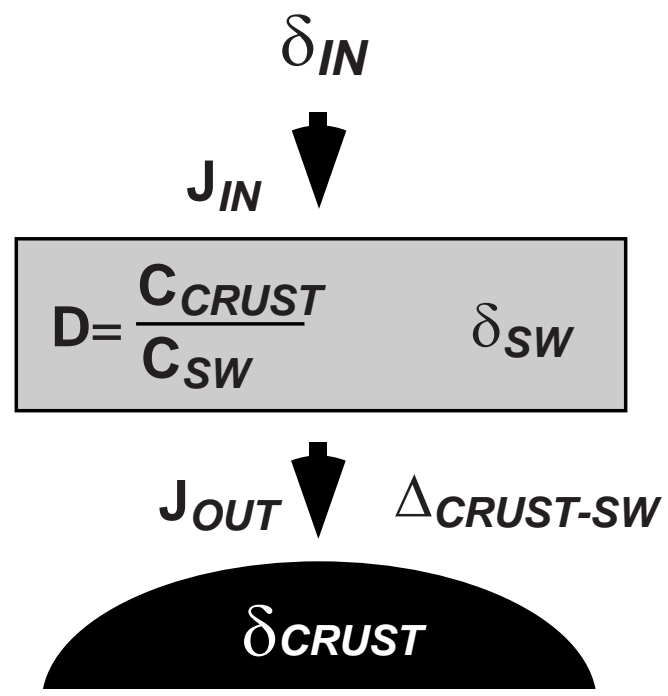

(b)

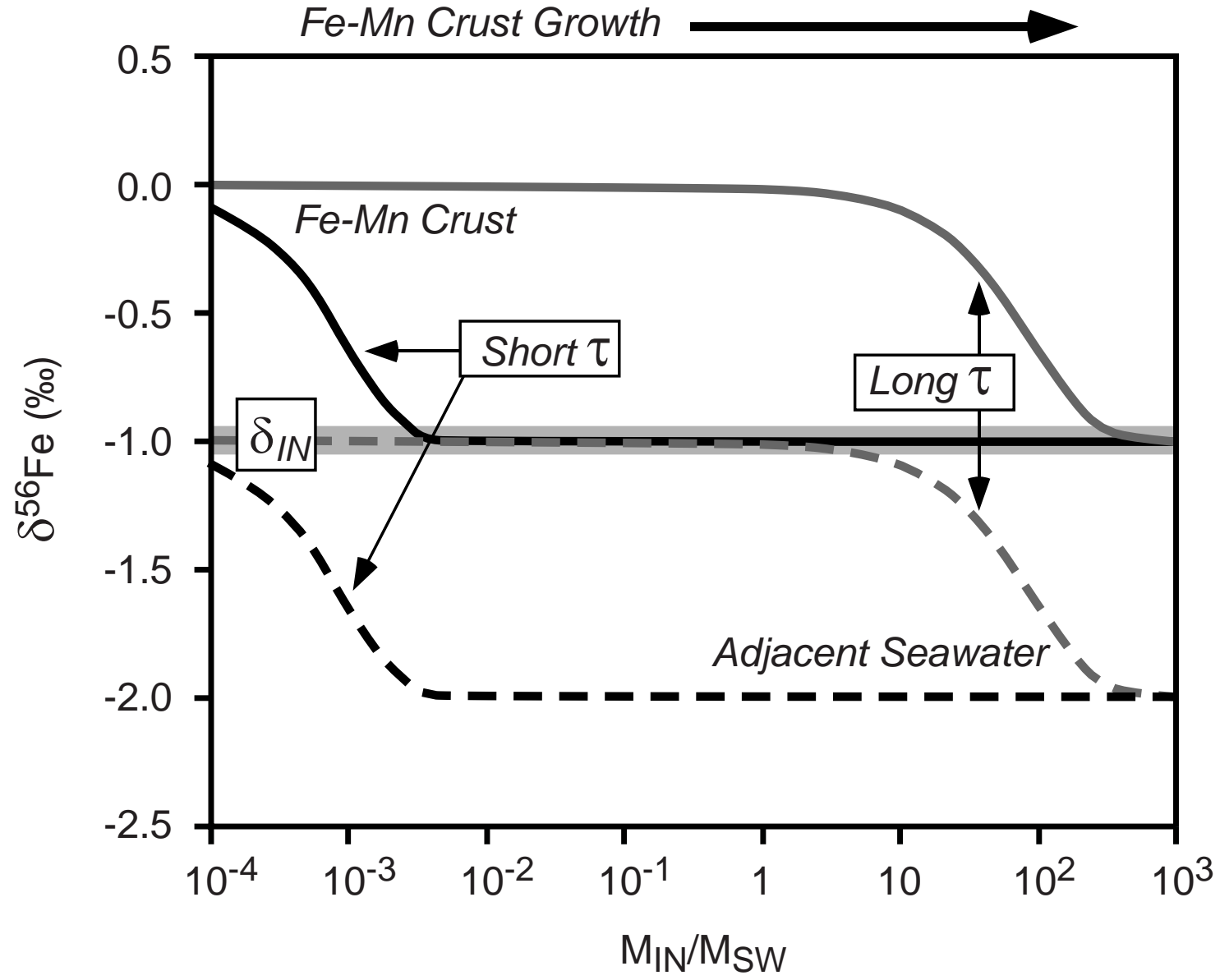

